
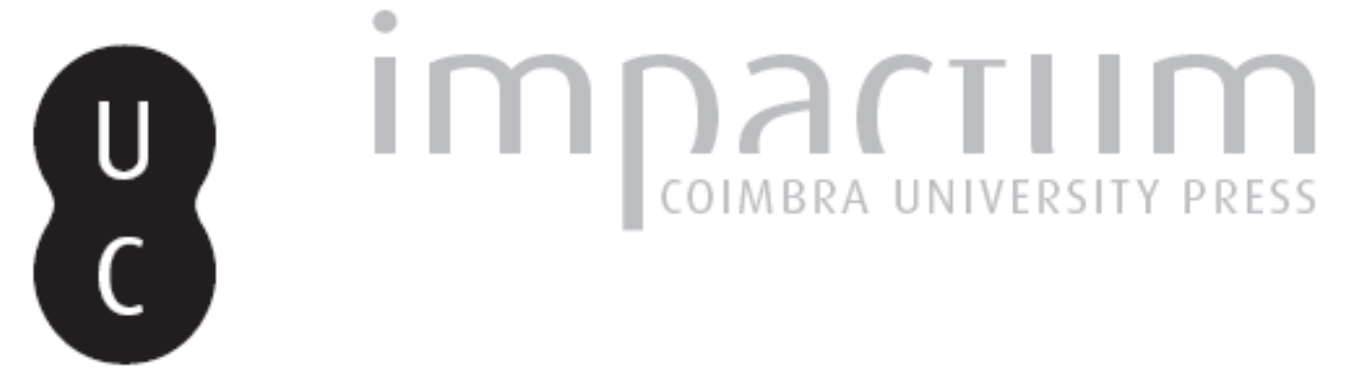

\title{
Bronze Final e a Idade do Ferro na região de Lisboa: um ensaio
}

Autor(es): $\quad$ Cardoso, João Luís

Publicado por: Imprensa da Universidade de Coimbra

URL persistente:

URl:http://hdl.handle.net/10316.2/45460

DOI:

DOI:https://dx.doi.org/10.14195/1647-8657_34_2

Accessed : $\quad$ 26-Apr-2023 11:13:48

A navegação consulta e descarregamento dos títulos inseridos nas Bibliotecas Digitais UC Digitalis, UC Pombalina e UC Impactum, pressupõem a aceitação plena e sem reservas dos Termos e Condições de Uso destas Bibliotecas Digitais, disponíveis em https://digitalis.uc.pt/pt-pt/termos.

Conforme exposto nos referidos Termos e Condições de Uso, o descarregamento de títulos de acesso restrito requer uma licença válida de autorização devendo o utilizador aceder ao(s) documento(s) a partir de um endereço de IP da instituição detentora da supramencionada licença.

Ao utilizador é apenas permitido o descarregamento para uso pessoal, pelo que o emprego do(s) título(s) descarregado(s) para outro fim, designadamente comercial, carece de autorização do respetivo autor ou editor da obra.

Na medida em que todas as obras da UC Digitalis se encontram protegidas pelo Código do Direito de Autor e Direitos Conexos e demais legislação aplicável, toda a cópia, parcial ou total, deste documento, nos casos em que é legalmente admitida, deverá conter ou fazer-se acompanhar por este aviso.

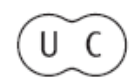


UNIVERSIDADE DE COIMBRA

FACULDADE DE LETRAS

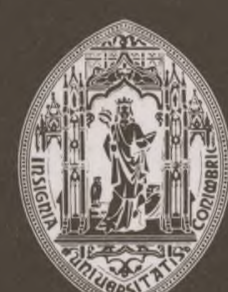

CONIMBRIGA

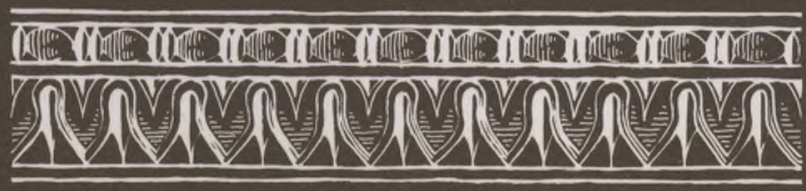

VOLUME XXXIV - 1995

INSTITUTO DE ARQUEOLOGIA 


\section{JoÃo LUÍS CARDOSO}

Professor da Universidade de Lisboa. Coordenador do Centro de Estudos Arqueológicos do Concelho de Oeiras - Câmara Municipal de Oeiras

O BRONZE FINAL E A IDADE DO FERRO

NA REGIÃO DE LISBOA: UM ENSAIO

«Conimbriga» XXXIV (1995), p. 33-74

RESUMO: Apresenta-se um ensaio da evolução do povoamento verificada na região de Lisboa, do Bronze Final ao fim da Idade do Ferro A evidente estratificação da sociedade do Bronze Final, com a correspondente existência de elites, detentoras de apreciável sobre produto económico, que concentravam o poder político-militar e das quais dependia a administração permanente e estável de territórios bem determinados, foram factores que muito beneficiaram o sucesso da penetração e difusão de produtos de origem fenícia, através de estabelecimentos - como a quinta do Almaraz (Almada) e a plataforma da Sé (Lisboa) - instalados em ambos os lados do grande estuário, controlando a navegação e o comércio nele efectuados, comportando-se complementarmente, como verdadeiros "lugares centrais" à escala regional, sedes do comércio de troca e pólos difusores dos produtos exógenos ali transaccionados. A estes, nos quais pontificam as cerâmicas fenícias - cujos elementos até agora suficientemente estudados não ultrapassam, quando datáveis, os meados do século VII AC - sucedem-se, ao longo do século VI AC, materiais ainda fortemente influenciados pelos protótipos orientais, porém quase exclusivamente produções locais ou regionais. Esta situação é consubstanciada nos materiais recolhidos não apenas nos primitivos estabelecimentos junto ao estuário, mas também nos obtidos em pequenos "casais agrícolas", descendentes directos daqueles que, no Bronze Final, se dispersavam pela região, vocacionados para uma exploração agropastoril permanente e intensiva dos férteis solos basálticos que se desenvolvem em torno de Lisboa. Tal continuidade no 
tipo de povoamento sugere a manutenção do modelo de organização social herdado do Bronze Final, que a introdução de novas tecnologias, novos gostos e outras concepções religiosas não terá alterado significativamente.

No século V AC emergem outras produções exógenas, de origem púnica; porém, a maioria dos materiais revela, como anteriormente, fabricos locais ou regionais, melhor adaptados aos gostos e necessidades dos respectivos utilizadores; acompanham-nos raros fragmentos de cerâmicas áticas (presentes em Almaraz e em Lisboa), aqui chegadas graças ao comércio púnico sediado em Gades.

A partir do século II AC, tais produções, onde avultam as ânforas neopúnicas de origem norte-africana, coexistem com outras, de origem itálica, consubstanciando uma III Idade do Ferro, tal como as anteriores de evidente raiz mediterrânea. Estes materiais ocorrem em contextos de carácter agrícola e familiar, idênticos aos que, desde o Bronze Final, pontuavam, de forma dispersa, o "agro olisiponense". Alguns destes lugares, cuja presença humana nalguns casos remonta ao Bronze Final, ou ao início da Idade do Ferro, continuaram a ser intensamente ocupados até à Alta Idade Média, consubstanciando um dos traços mais marcantes da presença humana proto-histórica da região.

A permanência de uma formação económica e social estável, bem como a continuidade dos estímulos culturais meridionais, estreitamente ligados ao comércio mediterrâneo, primeiro de origem fenícia, depois púnica e, finalmente, itálica, configuram um notável, prolongado e bem sucedido processo de aculturação, viabilizado e suportado pelos recursos naturais e condições oferecidas pela situação geográfica da região, que os habitantes souberam explorar activamente e com êxito.

SUMMARY: An essay is attempted on the evolution from Late Bronze Age to Final Iron Age on the region of Lisbon. The obvious social hiérarchisation and the existence of elites which concentrated the economic and military power and from whom a permanent and stable occupation of several territories was dependent, were the main factors that benefited the success for the entrance and act as factors of diffusion of Phoenician products. Phoenician establishments like Almaraz (Almada) and, possibly the platform of the Cathedral (Lisbon), installed or both sides of the estuary, controlled its navigation and commerce, behaved as "central sites", or heads of trade markets, and diffusion of exogenous products (ceramics, iron tools, glasses, etc.). The earliest of these importations - namely the Phoenician ceramics and the beads of vitreous mass - are not earlier than the second half of the VII century BC, like elsewhere (Alcácer do Sal, Abul, Santa Olaia, Rocha Branca). The Phoenician importations of the second half of the 
VII century $\mathrm{BC}$ were followed along the next century by materials still strongly influenced by oriental prototypes, but almost exclusively produced local or regionally. The fertile basaltic soils still continued to be intensively and extensively explored by a well succeeded farming economy. This evidence of continuity suggests that the social organization inherited from Late Bronze Age was not significantly altered by the introduction of new technologies or products, or even new religious conceptions.

In the $\mathrm{V}$ century $\mathrm{BC}$, accompanying the decay of the Phoenician commercial activity, other exogenous products appeared, from Punicorigin. Most of the ceramics, however, still indicate a local or regional specific characteristics, better adapted to the needs and traditions of its users; also present are rare fragments of atic ceramics (in Almaraz and Lisbon) due to the punie trade from Gades. This suggests that the primitive establishments founded by the Phoenicians still continued to be centres of trade of manufactured articles from the Mediterranean sea by local or regional productions (wine, cereals, salted meat and fish, salt, gold and, eventually, metals, like tin, from the Beiras region, carried out along the Tagus river by boat).

Since the beginning of the II century BC such productions, now represented by neopunic amphorae of african origin coexist with italic productions, corresponding to a new phase of the cultural and trade relations between this region and the Mediterranean area. Such materials occur in sites whose characteristics are similar of those occupied, in the same region, since the Late Bronze Age.

The permanence of a socially and economically stable system, closely related to a Mediterranean trade, firstly carried out by the Phoenicians, afterwords from Punic and finally from Italic origin, reveals a remarkable long, continuous and well suceeded process of aculturalisation, supported by the regional resources, as well as by the excellent geographical conditions offered by the Tagus estuary, which the inhabitants fully, activelly and successfully explored along the first millenium BC. 
(Página deixada propositadamente em branco) 


\section{O BRONZE FINAL E A IDADE DO FERRO NA REGIÃO DE LISBOA: UM ENSAIO}

\section{1 - INTRODUÇÃO}

A baixa Estremadura, na qual a região de Lisboa se insere foi, no decurso do Bronze Final e de toda a Idade do Ferro, densamente ocupada por comunidades que, no decurso deste longo lapso temporal, devido a factores diversos, aqui encontraram condições adequadas ao seu quotidiano e sobrevivência.

Com efeito, do Bronze Final à Idade do Ferro, durante mais de um milénio, foi esta região palco de notável "transformação na continuidade", consubstanciada em original processo de evolução económico-social, que, embora absorvendo estímulos externos de vária ordem, com dominância dos de origem mediterrânea, conduziu, progressivamente e sem sobressaltos, a uma formação económico-social organizada segundo modelo proto-estatal, em sintonia com a realidade que então pontificava em outras áreas peninsulares.

\section{2-0 BRONZE FINAL}

O Complexo Basáltico (ou Vulcânico) de Lisboa, cujos afloramentos cobrem extensa área, de Oeiras a Loures, desenvolvendo-se em forma de arco de círculo em torno de Lisboa, deu origem a solos muito férteis (vertissolos crómicos), até à actualidade intensa e extensamente explorados, sobretudo por culturas cerealíferas, que só a expansão urbana veio definitivamente interromper. Encostas suaves, boa exposição solar, disponibilidade de água, retida em aquíferos 
confinados, a pequena profundidade, foram outras tantas razões que justificaram a preferência que the foi conferida, afirmando-se como área agro-pastoril de excepção desde, pelo menos, a Idade do Bronze.

Deste modo se explica a ocupação dispersa aqui verificada, através de pequenas unidades de carácter familiar, dedicadas à exploração exaustiva do solo e à criação de gado bovino, ovino e suíno, desempenhando a caça papel insignificante, segundo os resultados do estudo faunistico dos restos recuperados na Tapada da Ajuda (CARDOSO et al., 1986). São as "granjas" ou "casais agrícolas" (MARQUES \& ANDRADE, 1974), cujo prolongamento, por vezes talvez em continuidade, pela Idade do Ferro e Período Romano, se encontra comprovado por testemunhos materiais. Este tipo de ocupação do território, aparentemente disperso e pouco hierarquizado, vem na continuidade do verificado no final do Calcolitico e inícios da Idade do Bronze, período correspondente aos derradeiros portadores das cerâmicas campaniformes, em que se verifica uma proliferação dos pequenos "habitats", abertos, em detrimento dos grandes povoados por vezes fortificados (CARDOSO, 1995 a), que então já se encontravam, em geral, abandonados.

A estação da Tapada da Ajuda, na área urbana de Lisboa, corresponde à única ocorrência deste tipo objecto de extensas explorações (CARDOSO et al, 1980/81; CARDOSO, et al., 1986; CARDOSO, 1987; CARDOSO, 1990; CARDOSO \& CARREIRA, 1993; CARDOSO, 1994 a, c; 1995 b). Situa-se em encosta suave, de exposição meridional e voltada para o estuário do Tejo, junto a linha de água, que nele desaguava. Tratar-se-ia de pequeno povoado, constituído por habitações dispersas. A única que foi escavada é uma casa de planta oval cujo eixo maior media cerca de $6 \mathrm{~m}$ de comprimento. $\mathrm{O}$ embasamento era constituído por muro, definido por uma dupla fiada de blocos basálticos não aparelhados, obtidos no local. Esta estrutura a única até agora reconhecida para a época e região em causa - tem afinidades com outras, do Bronze Final, reconhecidas em outras áreas do País. No Norte de Portugal, mencionam-se as dez cabanas exumadas na citânia de São Julião, Vila Verde, escavada por M. Martins (in FABIÃO, 1993); tal como se verificaria na casa da Tapada da Ajuda, apenas o embasamento era definido por alinhamento de blocos, sendo a super-estrutura constituída por elementos perecíveis, que não se conservaram. Outro exemplo, no centro do actual território português, é o das casas do monte de Santa Luzia, Viseu (Senna-Martinez, 
1994, p. 219, nota 3), bem como as encontradas no castro de São Romão, Seia (SenNa-MartineZ, 1989; FABĨ̃o, 1993, p. 91) e no outeiro dos Castelos de Beijos (Senna-Martinez, 1994). No sul, foram identificadas duas casas deste tipo no povoado de Neves II, subjacentes a habitações de planta rectangular da Idade do Ferro (MAIA \& MAIA, 1986). Pode concluir-se, deste modo, que a casa da Tapada da Ajuda se integra em modelo bem conhecido e de larga distribuição geográfica no Bronze Final.

As casas de planta oval foram consideradas como testemunhos de influências centro-europeias no Ocidente peninsular, através da meseta espanhola (GOMES, 1992, p. 110). Conquanto tal interpretação seja possível, é bem conhecida sua ocorrência em ambientes francamente mediterrâneos. É o caso das casas ovais de Cerro del Real de Galera, Granada e da colina de Los Quemados, Córdova, entre outras (PELLICER, 1979/80, p. 237, nota 52). Saliente-se que, já no final do Calcolitico, época do campaniforme inciso, tal modelo era conhecido na região de Lisboa, como se comprova pelas duas cabanas postas a descoberto em Leceia, Oeiras (CARDOSO, no prelo d), pelo que uma evolução regional é talvez a hipótese mais provável.

PELLICER (1979/80) situa no Bronze Final antigo - a que pertence a Tapada da Ajuda - os exemplos apresentados do sul peninsular. Com efeito, as cinco datas de radiocarbono indicam, depois de calibradas, época precoce do Bronze final. Os resultados foram os seguintes, após calibração utilizando a curva de PEARSON \& STUIVER ("Radiocarbon", 28 (2B), 1986, p. 839-862), considerando intervalo de confiança de dois sigma, correspondente a $95 \%$ de confiança (resultados inéditos):

ICEN - 100 (ossos) - $3000 \pm 40 \mathrm{BP}-1381-1113 \mathrm{cal} \mathrm{AC;}$

ICEN - 184 (carvões) - $3000 \pm 100 \mathrm{BP}-1466$ - $962 \mathrm{cal} \mathrm{AC;}$

ICEN 96 (conchas) - $3450 \pm 40 \mathrm{BP}-$ corrigida $-3090 \pm 50 \mathrm{BP}-$ 1484 - $1237 \mathrm{cal} \mathrm{AC}$;

ICEN 97 (conchas) - $3370 \pm 50 \mathrm{BP}$ - corrigida - $3010 \pm 60 \mathrm{BP}$ 1403 - $1067 \mathrm{cal}$ AC;

ICEN 99 (conchas) - $3340 \pm 40 \mathrm{BP}$ - corrigida - $2980 \pm 50 \mathrm{BP}$ 1377 - $1058 \mathrm{cal}$ AC.

Considerando a função densidade de probabilidade resultante da combinação das cinco datas, podemos atribuir o respectivo contexto aos séculos XIII ou XIV AC (informação de A. Monge Soares, que agradecemos). 
Tais resultados estão conformes, com efeito, às informações obtidas do estudo arqueológico dos materiais. Assim, entre os milhares de fragmentos cerâmicos observados, não se identificou um único da cerâmica com ornatos brunidos, que seria característica, como na Andaluzia, da última etapa do Bronze Final (TeJerA-Gaspar, 1980; BELÉN et $a L$, 1983). Esta jazida corporiza, pois, um momento inicial do Bronze Final, ou Bronze Final I, hipótese formulada pelo signatário (CARDOSO, 1990) e seguida por outros (GOMES, 1992 b).

As cerâmicas com ornatos brunidos foram identificadas pela primeira vez no território português por E. da Cunha Serrão (CARDOSO, 1995 d). Aceita-se que a emergência de tais cerâmicas corresponda a influxos mediterrâneos, actuantes desde o século XI AC, os quais se evidenciam, de forma paradigmática, no monumento da Roça do Casal do Meio, Sesimbra (SPINDLER et al., 1973/74), atribuível aos finais do século X ou começos do IX AC (GOMES, 1995 a), o qual continha um grande vaso com ornatos brunidos. Na Andaluzia, a tal período, de fins do século $\mathrm{X}$ a inícios do VIII AC, corresponde fase cultural designada por "Horizonte de Huelva", "período proto-orientalizante" ou "pré-colonial" (ALMAGRO, 1973, 1990), cujo terminus coincide com a data da instalação das primeiras colónias e feitorias fenícias.

A região de Lisboa correspondia, então, a espaço geográfico onde se cruzavam influxos atlânticos e mediterrâneos. Não devem, contudo, estes últimos ser excessivamente valorizados, mesmo que sejam atribuídos às actividades comerciais desenvolvidas pelos fenícios, sem requererem a sua fixação efectiva ao território. De facto, a própria cerâmica de ornatos brunidos evidencia regionalismo marcado, sendo os exemplares do centro e sul de Portugal - onde coexistem formas abertas e fechadas - quase exclusivamente decorados no exterior, enquanto que na Andaluzia a decoração se circunscreve à parede interna de formas abertas. Tal regionalismo poderá entender-se, pois, como expressão de realidades culturais diversas, como diferentes eram, também, as características económicas e sociais das respectivas comunidades. Por outro lado, estão bem comprovados os influxos culturais mediterrâneos que, desde o Neolítico antigo, e no decurso de todo o Calcolitico, actuaram, de forma marcante, na região em apreço, sem que por isso sejamos obrigados a considerar um Neolítico ou um Calcolitico "orientalizante". Os achados metálicos de objectos de prestígio ou de culto, dos séculos XI a VIII AC, embora documentem importante intercâmbio entre o sul peninsular e o Mediterrâneo central 
(Sardenha, Sicília) e, mesmo, oriental (Chipre), nada dizem quanto aos responsáveis pela sua difusão; os Fenícios poderiam, deste modo, ter apenas recuperado circuitos comerciais já existentes (AUBET, 1994, p. 186). Com efeito, estão referenciadas cerâmicas calcolíticas de origem anatólica, na região de Alicante (GONZÁLEZ PRATS et ai, 1995), sem que saibamos algo sobre os mecanismos de difusão e chegada de tais materiais provindos do outro extremo do Mediterrâneo. Idêntica observação é válida para as cerâmicas micénicas, cuja cronologia se situa entre 1300 e 1100 AC, recolhidas em Montoro, Cordo va (CRUZ, 1990).

No que ao território português diz directamente respeito, GOMES (1992 b) assinala a existência de "contas de pasta vítrea translúcidas da necrópole da Idade do Bronze da Atalaia (Ourique), com origem egípcia ou micènica ... “ (p. 27), figuradas por SCHUBART (1965). A confirmar-se tal observação e, a menos que sejam intrusões mais modernas, tratar-se-ia da primeira ocorrência documentada em território português, de produtos importados em época situável entre 1500 e 1400 AC. Outros indícios de "significativas trocas comerciais com os comerciantes de metais originários do Mediterrâneo oriental a partir da segunda metade do II milénio a. C." (idem, p. 27) seriam, segundo o mesmo autor, as representações de armas, machados, espadas e punhais, insculturados nas chamadas esteias alentejanas. Tais indícios suportariam a hipótese de contactos com o oriente mediterrâneo, de onde proviriam, especialmente, objectos sumptuários, sem que a sua presença force a extensão, à região em apreço, da aceitação do discutível período pré-colonial ou protoorientalizante da Andaluzia, defendido por ALMAGRO-GORBEA $(1973 ; 1990)$.

A riqueza da Estremadura no Bronze Final baseava-se essencialmente em dois factores naturais: a fertilidade das suas terras, propícias às actividades agropastoris, e consequentemente à produção de excedentes, susceptíveis de comercialização, e a sua excelente posição geográfica, já por outros valorizada (KALB, 1980), capaz de assegurar a articulação do comércio atlântico com o mediterrâneo, tanto através de navegação de cabotagem, ao longo da costa, como utilizando rotas terrestres ou fluviais (desempenhando neste aspecto importância fulcral o rio Tejo), já existentes. O enriquecimento destas comunidades estaria assim justificado, sem que seja necessário recorrer a outros factores, como a exploração do sal e do ouro, ambos suscep- 
tíveis de se obterem no estuário do Tejo ou no litoral oceânico adjacente. Assim se explicará a variedade dos achados metálicos do Bronze Final. Um dos exemplos mais expressivos é constituído pela espada pistiliforme recolhida no Tejo, em Cacilhas; corresponderá a fase inicial do Bronze Final, em que predominaria o fabrico de armas (GOMES, 1992 b), característico de um comércio trans-regional, atlântico-mediterrâneo.

A espada de Cacilhas poderá relacionar-se com oferendas a divindades aquáticas, então muito em voga por toda a Europa. De facto, a recuperação de armas do Bronze Final em dragagens fluviais é frequente. Já CARTAILHAC $(1886, \quad$ p. 200) declarava: “... des renseignements donnés par l'Histoire permettent de croire qu'une partie, très petite si l'on veut, mais notable, encore, de ces cachettes de bronze, doit son origine à des pratiques religieuses et qu'elles constituent des dépôts sacrés". Para alguns investigadores, o elevado grau de fragmentação de certas peças seria ainda indício de práticas rituais efectuadas no âmbito das referidas oferendas. Coombs \{in FERNÁNDEZ-MANZANO, 1984), referindo-se a depósitos ingleses, recorda que o número de achados subaquáticos aumenta consideravelmente do Bronze médio para o Bronze Final, explicando-se tal fenómeno pelo desenvolvimento daquelas oferendas. Ao encontro desta hipótese, PAUTREAU et al (1983/84) observam que, no Bronze antigo e médio, predominam as peças inteiras, enquanto que os depósitos do Bronze Final possuem, em percentagens variáveis, objectos partidos intencionalmente.

A crescente invocação de divindades aquáticas, ou do culto das águas, que parece cada vez mais frequente à medida que se aproxima o fim da Idade do Bronze, poderá estar relacionada com eventual degradação climática então verificada, tal como sugeriu Burgess \{in FERNÁNDEZ-MANZANO, 1984). Com efeito, a transição da Idade do Bronze para a Idade do Ferro seria caracterizada, ao menos nalgumas regiões europeias - para o território português, a falta de estudos impede quaisquer certezas - por marcado arrefecimento climático (THEOBALD, 1972), embora não no sentido da aridez. Nesse período de possíveis dificuldades, exacerbar-se-ia o espírito religioso; daí o elevado número de ocorrências a que se poderá atribuir carácter ritual (CARDoso et al, 1992).

O final do Bronze Final na região em estudo, tal como em outras, seria acompanhado pelo aumento de peças metálicas de carácter 
utilitário, mais acentuadamente de fabrico local do que as armas produzidas anteriormente. Este facto encontra-se excelentemente ilustrado pelo molde de foices de Rocanes, Sintra (FONTES, 1915), usado para fundir exemplares de bronze ("foices de tipo Rocanes") como o recolhido em Pedreiras, Sesimbra (SERRÃO, 1966), que substituirão as foices utilizando lascas de sílex com bordo denteado, encabadas em madeira, ainda em voga no início do Bronze Final, como se conclui pelas centenas de exemplares recolhidos na Tapada da Ajuda (CARDOSO et al, 1980/81; CARDOSO et ah, 1986).

Pode, pois, aceitar-se que uma crescente afirmação da capacidade económica da Estremadura, no decurso do Bronze Final, decorreria, ao menos em parte, da melhoria das capacidades produtivas, na sequência da introdução de novos e mais eficazes instrumentos agrícolas, os quais, na verdade, não foram acompanhados de melhorias ao nível da farinação; na Tapada da Ajuda, continuam a utilizar-se mós do tipo neolítico, cuja sobrevivência na Idade do Ferro se encontra igualmente ilustrada no "casal agrícola" de Rei Mouro, Sintra (SERRÃO, 1980, Fig. 6). A realidade de uma metalurgia local, destinada a consumo próprio e, ao mesmo tempo, a comercialização extra-regional, pode, assim, ser vista como causa e, ao mesmo tempo, consequência, da melhoria das condições económicas e do poder de compra das comunidades aqui instaladas.

Cabe ainda referir, entre os produtos de bronze, as fíbulas com enrolamento no arco, como a do monumento da Roça do Casal do Meio, o primeiro exemplar deste tipo exumado em Portugal (SPINDLER et al, 1973/74) e cuja origem mediterrânea é evidente, tal como o pente de marfim que a acompanhava - denotando a existência de produtos sumptuários, além dos metálicos - é norte-africana. A distribuição daquele tipo de fíbula no território peninsular e além-Pirenéus (SENNAMARTINEZ, 1994, p. 225) ilustra, exemplarmente, a sua difusão continental e atlântica, através do comércio trans-regional. Estas fíbulas têm sido, segundo o referido autor, confundidas com as fíbulas "de codo", ou "cotovelo", cujos primeiros exemplares portugueses foram recentemente publicados (CARREIRA, 1994, Fig. 9 e Est. 33, n. 1), além do exemplar gravado na estela de Ervidel II, do século IX AC ou inícios do seguinte (GOMES, 1995 b). Sendo fíbulas de origem igualmente mediterrânea, mais precisamente cipriota, como COFFYN \& SION (1993, Fig. 5) evidenciaram através da respectiva distribuição geográfica, constituem, tal como as anteriores, exemplo frisante do 
comércio mediterrâneo-atlântico do Bronze Final, de produtos sumptuários.

Tais rotas comerciais a longa distância, estáveis e regulares, pressupõem comunidades socialmente estruturadas e repartidas por territórios bem delimitados e permanentes. De facto, a crescente hierarquização social desta sociedade pode ser vislumbrada através da evolução das esteias funerárias, no decurso do Bronze Final, nas quais a representação da figura do chefe se encontra progressivamente afirmada.

Aquela situação, bem patente nas comunidades que no decurso do Bronze Final habitaram a região de Lisboa, teria sido, como se disse, em parte viabilizada pela acumulação de riqueza resultante de uma bem sucedida adaptação ao território da baixa Estremadura. Da sua exploração activa, tanto ao nível do aproveitamento ou captação dos recursos potenciais naturalmente disponíveis, como ao nível dos benefícios económicos resultantes da sua excelente posição geográfica, favorável à recolha de mais-valias da redistribuição comercial dos produtos metálicos aqui manufacturados ou do próprio minério em bruto, resultou uma nova ordem social, progressivamente imposta. E assim que, naturalmente, emergem povoados fortificados, como o do Cabeço da Amoreira, Loures (FABIÃo, 1993 - alguns talvez nunca abandonados desde o Calcolitico - onde se sediaria o segmento dominante da sociedade, em que pontificava a figura do "chefe", rodeado da "elite" guerreira que o acompanhava e, talvez, dos metalúrgicos, a quem cabia actividade de grande projecção económica.

Pastores e agricultores, sobre os quais recaía a função de assegurar o sustento dos grupos mais destacados socialmente, não directamente ligados às actividades produtivas, dispersar-se-iam pelos férteis campos adjacentes, que continuaram a ser intensamente explorados. Enfim, as funções litúrgicas poderiam ser já desempenhadas por um grupo específico, entendido, tal como os anteriores, como expressão da segmentação e estratificação social crescentemente afirmadas. Os dois indivíduos - adultos e do sexo masculino sepultados no monumento da Roça do Casal do Meio, Sesimbra (SPINDLER et al., 1973/74) - cuja afinidade com os tholoi micénicos tardios, dos finais do II milénio AC são evidentes (GOMES, 1995 a) não se encontravam, significativamente, acompanhados de armas, apesar da elevada categoria social que evidentemente detinham no seio da sua comunidade, aliás expressamente afirmada por outros objectos 
de prestígio (pinça, fíbula, pente), igualmente elementos comuns nas estelas estremenhas do Bronze Final.

Em resumo, a evolução económico-social verificada no decurso do Bronze Final na região de Lisboa explica a emergência de povoados em sitios com boas condições de defesa, fortificados ou não, no fim deste período (Bronze Final II).

Com efeito, todos os lugares altos que, na região de Lisboa, revelaram ocupações do Bronze Final, forneceram cerâmicas de ornatos brunidos, o que não acontece com os sítios abertos, de índole agro-pastoril, nos quais escasseiam tais cerâmicas. É o caso dos povoados de altura do Cabeço dos Moinhos, Mafra (VICENTE \& ANDRADE, 1971), do Castelo dos Mouros, Sintra (CARDOSO, em preparação) ou do Cabeço do Mouro, Cascais (CARDOSO \& CARDOSO, no prelo), para só citar três casos de diferentes concelhos em torno da capital. Todos estes locais revelaram peças de bronze, avultando as seis xorcas do Cabeço dos Moinhos constituindo provavelmente um esconderijo, como o descoberto em elevação próxima daquela, o Cabeço do Lexim, Mafra (ARNAUD, 1971, p. 131), integrando dois machados de aselhas e alvado, sem vestígios de utilização e aparentemente produzidos no mesmo molde, ou o achado de machado de bronze com uma aselha, associado a lâmina de punhal, em pequena gruta do morro de Monte Sereno, Sintra (PEREIRA, 1957, p. 21-22).

A ocorrência de tais "tesouros" em locais de altura habitados, ou próximo deles, reforça o que antes se disse sobre a sua ocupação por um segmento da comunidade, já diferenciado daquele que se ocuparia, nos campos adjacentes, da agricultura e do pastoreio. De tais lugares, as "elites", que os ocupavam, além de neles se poderem mais vantajosamente defender, controlariam vastos territórios e as vias de comunicação que os atravessavam, e que asseguravam o comércio trans-regional de produtos metálicos, à semelhança do verificado em outras regiões do País (SEnNA-Martinez, 1994, p. 226). Com efeito, os processos sociais observados na região de Lisboa, no decurso do Bronze Final, são indissociáveis de uma realidade muito mais ampla, como seria lógico em comunidades francamente voltadas para as relações económicas trans-regionais, que veiculavam estímulos de carácter supra-regional, de vária ordem.

De salientar que, na Idade do Bronze do Baixo Alentejo, os povoados de altura surgem apenas no Bronze Final (PARREIRA, 1995, 
p. 132), comportando-se como lugares onde, segundo o referido autor, se sediaria o poder instituido.

$\mathrm{O}$ enriquecimento resultante das actividades produtivas (agricultura), comerciais (redistribuição de metais, manufacturados ou não) e industriais (metalurgia do bronze e do ouro, exploração deste metal e do sal), corresponderia a processo crescentemente afirmado no decurso do Bronze Final. A fundação de sítios fortificados, a partir dos quais se administrariam territórios circunscritos e bem definidos seria, apenas, uma expressão da complexificação social em curso. Não se evidencia, no entanto, a ascendência de determinados povoados em relação aos outros, o que significa que ainda não poderemos considerar a existência de verdadeiros "lugares centrais".

A presença das referidas elites, enriquecidas por qualquer das causas expostas é uma realidade bem demonstrável na região de Lisboa, no final do Bronze Final. Saliente-se o extraordinário colar de ouro da Quinta da Penha Verde, Sintra, com o peso de 1260 g, descoberto ocasionalmente em uma sepultura (PEREIRA, 1896). Tratase de peça única, que, pelas características e decoração geométrica que ostenta, se pode situar no final do Bronze Final, ou na transição para a Idade do Ferro (ARMBruster, 1995).

Em resumo, a existência de povoados onde se sediariam comunidades independentes e certamente concorrentes entre si, não apenas na posse das melhores terras, mas, sobretudo, no domínio dos circuitos comerciais trans-regionais configura uma sociedade já firmemente hierarquizada - ao contrário do defendido para a região tartéssica, no Bronze Final (WAGNER, 1995, p. 115) - e organizada, francamente aberta a estímulos culturais de origens diversas, mediterrâneos e atlânticos, viabilizados e suportados pelas intensas actividades comerciais aqui efectuadas, que estiveram, afinal, na origem do seu próprio enriquecimento. Era este o ambiente económicosocial da região de Lisboa nos tempos ¡mediatamente antecedentes dos primeiros contactos directos com comerciantes fenícios, sendo assim francamente propício, sobretudo pela presença de uma sociedade já hierarquizada, à rápida afirmação e difusão dos produtos resultantes de tais contactos (AUBET SEMMLER, 1990, p. 33).

Além das considerações anteriores sobre práticas litúrgicas do Bronze Final, importa salientar que boa parte das cerâmicas com ornatos brunidos da região estremenha provém de grutas naturais, sem que a elas se possam associar práticas funerárias; a escassez ou 
ausência de testemunhos antropológicos compatíveis, não é explicável por condições de conservação adversas. Assim, é crível que a ocupação das grutas se possa relacionar com áreas cultuais. Na região que nos interessa, salienta-se a gruta do Correio Mor, Loures (CARDOSO, no prelo c) e a Lapa do Fumo, Sesimbra, onde, pela primeira vez, tais cerâmicas foram reconhecidas e caracterizadas, por E. da Cunha Serrão, na década de 1950 (CARDOSO, 1995 d).

\section{3 - A IDADE DO FERRO}

No decurso de escavações efectuadas em Portugal nos anos 80 e já na presente década, foi documentada, de forma categórica, a existência de povoados que receberam directamente produtos de fabrico oriental, através do comércio fenício, efectuado ao longo do litoral atlântico. Tais descobertas vieram revolucionar o "dogma" da inexistência de estabelecimentos fenícios para Oeste de Cádis (SCHUBART, 1982). Com efeito, as características de implantação destas estações são condizentes com a intensa navegação e comércio com que estavam relacionadas. Correspondem a colinas, dominando vastos estuários, e em fácil comunicação, a um tempo, com o litoral oceânico adjacente e com o interior, através da via fluvial respectiva, propícia à circulação e ao escoamento de produtos, cuja existência era, afinal, a principal justificação para a presença, neste confim do mundo mediterrâneo, de comerciantes fenícios. Tal presença foi atribuída, no baixo vale do Tejo (alcáçova de Santarém) aos inícios do século VIII AC (ARRudA, 1993). Porém - na ausência de estudos concludentes sobre materiais exumados - tal cronologia baseia-se, apenas, em uma única data de radiocarbono, de limitada representatividade (ICEN $532-2640 \pm 50 \mathrm{BP}$ ), a qual, depois de calibrada pela curva de Pearson e Stuiver, para 2 sigma, correspondente a $95 \%$ de probabilidade, forneceu o intervalo de $900-780 \mathrm{cal} \mathrm{AC}$.

Por outro lado, as duas datas obtidas no povoado do Almaraz, situado em colina em forma de esporão debruçado sobre o estuário do Tejo, defronte de Lisboa, obtidas, respectivamente sobre conchas e ossos recolhidas na parte inferior de uma fossa de acumulação de detritos foram as seguintes (BARRos et al, 1993): ICEN - $914-2640 \pm 50$ BP e ICEN - $926-2660 \pm 50 \mathrm{BP}$, correspondem os intervalos, respectivamente, de 900-780 cal AC e de 910-790 cal AC, para 95\% de probabilidade. 
A elevada antiguidade destas três datas deve, por ora, ser interpretada com reserva. Com efeito, no Almaraz, os materiais mais antigos, recolhidos no mesmo contexto fechado dos materiais datados - uma fossa de acumulação de detritos, por certo rapidamente preenchida - susceptíveis de serem datados com segurança, não ultrapassam o século VII AC (CARDOSO, 1990; BARROS et 1993); além disso, o único estabelecimento de fundação inquestionavelmente fenícia - Abul, no baixo Sado (MAYET \& SilvA, 1993, 1994), não ultrapassa os meados daquele século, tal como se verifica com a ocupação do castelo de Alcácer do Sal (SILVA et al., 1980/81), cujas características de implantação são idênticas às da alcáçova de Santarém ou do povoado de Almaraz.

Assumem a maior importância em tais ocupações orientalizantes, as cerâmicas de engobe ou verniz vermelho, características da primeira fase da presença fenícia peninsular, dos séculos Vili e VII AC (SCHUBART, 1988 a). Na área de Lisboa, reconheceram-se exemplares destas cerâmicas em Almaraz e no morro da Sé de Lisboa. No primeiro daqueles sítios, os quase dois mil fragmentos recuperados em fossa de acumulação de detritos, correspondem ao conjunto mais numeroso até agora estudado em Portugal (BARROS et ai, 1993). No seio de tais cerâmicas, os pratos revestem-se de grande interesse no estabelecimento de cronologias, através da respectiva largura do bordo (SCHUBART, 1982, 1988 a). Em Almaraz, observou-se a seguinte distribuição:

- largura do bordo até $35 \mathrm{~mm}$ - 2 exemplares;

- largura do bordo até $55 \mathrm{~mm}$ - 4 exemplares;

- largura do bordo superior a $55 \mathrm{~mm}$ - 12 exemplares.

Tendo presentes as palavras de SCHUBART (1988), apenas um número representativo de exemplares poderá conduzir a resultados cronológicos credíveis. Isto significa que, se acaso considerássemos apenas os pratos com larguras do bordo menores (os dois exemplares com $25 \mathrm{~mm}$ ) obteríamos uma cronologia para o sítio do último terço do século VIII AC, tomando como comparação directa os pratos bem datados dos estratos II e III de Tiro (SCHUBART, 1982, Fig. 18) e não do fim do século VII AC, ou início do seguinte como indica o conjunto. Acresce que apenas um único estabelecimento fenício de todo o litoral espanhol tem cronologia tão recuada, e ainda assim apenas compatível com o limite superior do intervalo a dois sigma: das datações atrás referidas trata-se do Morro de Mezquitilla, Málaga (SCHUBART, 1982). 
Cremos, por conseguinte, ser imperiosa a confirmação de idéntica antiguidade para locais tão periféricos e longínquos como Lisboa e (especialmente) Santarém através das análises arqueográficas das cerâmicas recolhidas, ainda não efectuadas.

A cerâmica de verniz vermelho está representada em Almaraz por um conjunto numeroso de taças carenadas, de paredes bicóncavas, que não têm equivalente conhecido em outra estação peninsular. Tanto em Huelva (RUFETE TOMICO, 1988/89), como em Toscanos (SCHUBART et al, 1969; SCHUBART \& MAASS-LINDEMANN, 1984) ou Morro de Mezquitilla (SCHUBART \& NIEMEYER, 1976) ou outros estabelecimentos fenícios peninsulares, tal forma não é conhecida. Este facto revela a notável diversificação das produções cerâmicas de inspiração oriental, correspondentes ao apogeu da presença fenícia peninsular, nos séculos VII e VI AC. Deste modo, pode admitir-se que, após a introdução de formas de evidente inspiração e fabrico orientais, as técnicas de produção foram rapidamente apreendidas pelos peninsulares, que as aplicaram ao fabrico de recipientes mais ao seu gosto, necessidades e tradições. As taças carenadas bicóncavas do Almaraz poderiam ter sido fabricadas em qualquer das feitorias fenícias ocidentais ou, eventualmente, no próprio local. De facto, é tentador atribuir a este estabelecimento o carácter de feitoria fenícia, de tal forma é esmagadora, no conteúdo da fossa de detritos referida, a predominância de cerâmicas fenícias ou de imitação fenícia, nas quais se inscrevem também as ânforas e os pythoi, ou outros grandes recipientes, ornados frequentemente de pinturas em bandas polícromas, vermelhas, brancas, negras e outros desenhos geométricos, como os reticulados, a que se associam as cerâmicas cinzentas, nas suas diversas variantes. Tal hipótese é reforçada, se se considerar a evidente semelhança das condições geomorfológicas do local, a que não faltava uma enseada na base da colina (a actual Cacilhas), propícia, ainda na actualidade, a ancoradouro, ou mesmo à acostagem de navios, como se observa em diversos estabelecimentos fenícios peninsulares. É o caso do Cerro del Prado, na embocadura do rio Guadarranque (ARTEAGA et al., 1988, Abb. 6) e de Mondila (Arteaga et al, 1988, Abb. 5), situados no topo ou na encosta de colinas. Em extremo de esporão, como o Almaraz, implantou-se o estabelecimento fenício de rio Antas (ARTEAGA et al., 1988, Abb. 3, n . 7), tal corno Toscanos, estação ocupada do último terço do século Vili a meados do século VI AC, situada em pequeno promontório dominando, de $18 \mathrm{~m}$ de altitude, a embocadura do rio de 
Vêlez, Málaga (SCHUB ART, 1982, Fig. 8; SCHUB ART, 1988 b, Abb. 1). Tais paralelos reforçam, pois, as características de carácter comercial do local, bem evidenciadas pelo espolio exumado.

$\mathrm{Na}$ margem oposta do grande estuário, em pequena plataforma do morro onde se implanta a Sé de Lisboa, voltada para o Tejo, foram também recuperados vestígios de ocupação idênticos aos de Almaraz. Os materiais exumados por Vergilio Correia, no início do século, incluem pratos de verniz vermelho (um exemplar com $27 \mathrm{~mm}$ de largura do bordo), ânforas fenícias e pythoi com decoração de bandas pintadas, vermelhas e negras, além de cerâmicas cinzentas e comuns (CARdoso \& CARreira, 1993, Fig. 5, $\mathrm{n}^{\circ}$. 1 a 4). No conjunto, os materiais publicados indicam a primeira metade do século VI AC. As escavações ali recentemente efectuadas vieram ilustrar tal ocupação com importante conjunto de cerâmicas fenícias, atribuído aos séculos Vili - VII AC (MATOS, 1994), embora tais atribuições cronológicas careçam de confirmação por estudo específico, ainda não efectuado.

A relação entre a plataforma onde se encontraram tais materiais e o alto que a domina, actualmente ocupado pelo castelo de S. Jorge, levou AMARO (1993, p. 186) a considerar a "hipótese da existência de um povoamento indígena na área do actual castelo e a instalação de um entreposto comercial na plataforma sobranceira ao rio e onde se situa a sé de Lisboa". A discussão de tal modelo, em que a um povoado pré-existente, do Bronze Final, se teria sucedido outro, de fundação fenícia, coevo ou não daquele, coloca-se igualmente em Almaraz, exactamente nos mesmos moldes e com maior riqueza de elementos materiais. Aqui, observou-se distribuição diferenciada do espólio orientalizante, face aos testemunhos do Bronze Final, os quais se espalhavam em uma plataforma sobranceira, do mesmo esporão rochoso, em estrato muito erodido, com máximo de cerca de $10 \mathrm{~cm}$ de espessura.

Não é crível que os dois locais tenham coexistido. Com efeito, a percentagem da distribuição espacial de cerâmicas indígenas na plataforma inferior é quase sempre menor que $10 \%$, e isto apesar de boa parte delas poderem ter derivado, por gravidade, dos sítios mais altos da estação, onde predominavam (BARROS et al., 1993, Fig. 1). Por outro lado, dos 21947 fragmentos recolhidos na fossa de acumulação de detritos existente na plataforma inferior, apenas 3,6\% eram de cerâmicas manuais indígenas, percentagem que justifica, como antes se referiu, o carácter exógeno do estabelecimento, cujo cunho orientalizante é 
demonstrado pelo extraordinàrio conjunto de 1926 fragmentos de cerâmicas de verniz vermelho que ali se recolheram. Deste modo, a situação descrita configura-se semelhante tanto àquela que SCHUBART \& NIEMEYER (1976) depararam na feitoria fenícia de Morro de Mezquitilla, junto da desembocadura do rio Algarrobo, como à descrita na homóloga da foz do rio Guadiaro, Cádis (SCHUBART, 1987).

$\mathrm{Na}$ primeira daquelas estações, depois de referirem a presença de cerâmicas calcolíticas e da Idade do Bronze, incluido formas muito tardias destas últimas, declaram (p. 102, 103): "Esta fase tardia del poblado de la Edad del Bronce en el Morro de Mezquitilla, caracterizada únicamente por escasos hallazgos, corresponde cronologicamente al establecimento fenicio en este mismo lugar o por lo menos completamente en sus inmediaciones, según la respuesta que se dá a la pregunta de dónde estuvo la colonia fenicia. Habría que considerar los hallazgos prehistóricos de los estratos ya fenicios como las últimas huellas del poblado primitivo o de uno contiguo.

Hay, sin embargo, otra interpretación que explicaría los fenómenos arriba descritos y a la que puede atribuise tal vez incluso mayor verosimilitud: entre un poblado más antiguo de carácter puramente prehistórico y el establecimiento fenicio alli mismo pudo haber existido una interrupción en la continuidad. Pero hay que tener en cuenta la difilcultad de demonstrar por medio de urna excavación la existencia de un hiatus, especialmente tratándose - como en nuestro caso - de la cima de una colina, cuya superficie ha estado muy expuesta a los procesos de erosión (...)". Estas palavras aplicam-se integralmente a Almaraz servindo assim para reforçar os estreitos paralelismos entre a situação aqui observada e a respeitante a alguns dos estabelecimentos fenícios do litoral do país vizinho. Os autores consideram mais plausível, na sequência da discussão, a última hipótese por eles apresentada, aceitando que "Las ultimas construcciones de este poblado (...) podrían haber estado hace ya tiempo destruidas al establecerse una factoría fenicia sobre la cima del Morro de Mezquitilla, que entonces parecería de nuevo completamente virgen". E a hipótese que consideramos igualmente mais aceitável para explicar a situação verificada no Almaraz, e talvez na plataforma da Sé de Lisboa, embora aqui a falta de elementos não nos permita, sequer, aceitar a existência de um povoado indígena no alto da elevação.

Outro estabelecimento fenício, na foz do rio Guadiaro, Cádis, reforça a possibilidade de o Almaraz poder corresponder, na sua fase 
mais moderna, a uma feitoria fenícia. Também ali é nítida a diferenciação da distribuição espacial de materiais indígenas e orientalizantes. Porém, ao contrário do caso anterior, ambos os núcleos teriam coexistido. A hipótese que Schubart prefere admite uma influência directa do estabelecimento fenício sobre o vizinho povoado indígena; tal hipótese encontrar-se-ia corroborada pelo facto de, ali, ocorrerem crescentemente materiais orientalizantes, a partir dos estratos médios. Este caso aplica-se à situação observada no Almaraz, na hipótese de o núcleo indígena se encontrar habitado à data da chegada dos Fenícios: estes poderiam perfeitamente ter estabelecido a sua feitoria em zona adjacente, considerando as boas relações que pretendiam desenvolver com os autóctones.

Num caso ou noutro, isto é, estando o núcleo indígena do Bronze Final ainda ocupado ou já abandonado, chegaríamos à conclusão que consideramos mais aceitável: o carácter exógeno do estabelecimento da plataforma inferior do Almaraz, compatível com uma feitoria fenícia.

Não é, contudo, legítimo estender tal conclusão à margem fronteira do estuário, até que elementos de maior pormenor e mais exaustivos se publiquem das importantes escavações ali realizadas pelo IPPAR e dirigidas por J. L. de Matos e C. Amaro.

Seja como for, não será a curta distância que separa aquela estação do Almaraz que inviabilizará a hipótese de, também ela, poder corresponder a uma feitoria fenícia. As feitorias fenícias de Morro de Mezquitilla e de Toscanos encontram-se separadas apenas de alguns $\mathrm{km}$. Por outro lado, é de salientar que se trata de dois estabelecimentos situados em margens opostas de um grande estuário; teriam, pois, funções complementares no domínio do tráfego e comércio fluvial. Para além de promoverem o comércio com regiões bem diferenciadas, situadas nos respectivos "hinterlands", receberiam, sobretudo, os produtos escoados através do curso inferior do Tejo, sendo primordial o papel desempenhado pelo povoado da alcáçova de Santarém, já referido, complementado por outros, como o existente em Chões de Alpompé, onde DlOGO (1993) evidenciou ocupação documentada por ânforas fenícias do século VII AC.

Além da via fluvial, tanto o morro da Sé como o Almaraz seriam igualmente complementares, como elementos da via terrestre que ligaria Olisipo - topónimo que se adequaria ao de uma cidade turdetana (AlarcãO, 1990) - a Tartesso, em quatro dias (GOMES, 1992a). Com efeito, o Tejo transpor-se-ia em Cacilhas, no sopé dó esporão do 
Almaraz, tal como ulteriormente se continuou a praticar na época romana (ALARCÃO, 1992), e até à actualidade.

Tendo presente a advertência de Luis Marinho de Azevedo:

"Que Reyno? Que cidade?

que lugar humilde

não se prezaria de fundações antigas

e qualificadas?

Qual não pretende ser fundação

de Phenicios, Tyrios, Gregos,

Carthagineses, Romanos?",

SILVA (1960) apresenta e discute as numerosas hipóteses com que, ao longo dos séculos, se procurou explicar o nome de Lisboa. Entre elas, uma reveste-se de particular interesse para este estudo: trata-se da que foi formulada por Samuel Bochart, na segunda metade do século XVII, que supôs o vocábulo constituído por dois elementos fenícios, alis e $u b b o$, cuja significação é "enseada amena". Esta hipótese, que foi ulteriormente defendida pelo Visconde de Castilho, entre outros, está, de facto, conforme à realidade observada.

Quais os produtos que se transaccionariam nestes locais, os quais constituíam, afinal, o principal motivo da presença fenícia nesta finisterra?

E frequente apontar a riqueza aurífera do Tejo - o próprio topónimo árabe "Al-Madan”, “a Mina”, confirma-a. São de VASCONCELOS (1905, p. 24, 25) as seguintes palavras: "sem querer espraiar-me em citações, lembrarei apenas alguns autores. Ovídio diz, nas Metamorphoses, II, 251 : Quodque suo Tagus amne vehit, fluit, ignibus, aurum ...

Silicio Italico, nos Punicorum I, 155, falla do auriferi fontis, II, 404, das opibus Tagi, e em XVI, 560, tem o verso: Qua Tagus auriferis pallet turbatus harenis ...

em Catullo, XXIX, 20, figura o amnis aurifer Tagus; em Juvenal, III, 54-55, lê-se:

urum Omnis barena Tagi, quodque in mare volvitur a ...

ideia que se repete mais adeante, XIV, 298-299:

...aurum

Quod Tagus ... volvit...

e também se encontra em Lucano, na Pharsalia, VII, 755:

Quidquid Tagus expulit auri.

$\mathrm{O}$ ouro do rio tornou-se urna especie de logar communi nos

Conimbriga, 34 (1995), 33-74 
poetas, o que não quer dizer que também alguns prosadores o não citassem".

Entre eles, destaca-se Plínio-o-Velho, IV, 115: “O Tejo é famoso pelas suas areias auríferas".

Tais tradições ainda recentemente tinham expressão concreta. Com efeito, sabe-se que as areias pliocénicas que afloram para sul da foz do Tejo, ao longo da Península de Setúbal, têm uma longa história de exploração aurífera, provavelmente originária no Calcolitico. Naturalmente que hoje nada subsiste daqueles trabalhos nem, tãopouco, dos que se lhes sucederam. Na Idade Média, tais explorações constituíam uma fonte importante de abastecimento do precioso metal, gozando de privilégios especiais do Rei quem nelas trabalhasse, até finais do século XVI (os adiceiros).

Os trabalhos foram reactivados no início do século XIX e, ainda em 1832, se cunharam moedas de D. Miguel com o ouro dali extraído. CHOFFAT (1912/13) fornece os seguintes resultados da exploração, quando os trabalhos foram dirigidos por técnicos de nomeada:

- Andrada (5 anos e 4 meses) - 48,609 kg;

- Vandelli (4 anos eli meses) - 37,160 kg;

- Eschwege (1 ano eli meses) - 3,878 kg.

Tais montantes expressam o interesse de tais explorações, apenas abandonadas pelo encarecimento da mão-de-obra, situação que se manteve até o presente.

Outro metal que poderia ser processado em Almaraz era o ferro; com efeito, foram reconhecidos testemunhos da sua metalurgia, tal como em outros estabelecimentos fenícios do litoral meridional da Península, constituindo tal prática uma das evidências mais importantes das actividades industriais praticadas pelos Fenícios (SCHUBART, 1988 a).

O sal era outra matéria-prima de elevado valor em toda a bacia do Mediterrâneo, e que provavelmente foi comerciada pelos Fenícios. Além de poder ser exportado em bruto, o sal era indispensável à indústria de conservas e preparados piscícolas. A grande quantidade de restos ictiológicos recolhidos na fossa de acumulação de detritos do Almaraz parece demonstrar tal realidade.

Enfim, a grande riqueza agropecuária desta região possibilitava a produção de trigo, azeite e vinho, além de carnes, em quantidades tais que justificavam - se outros produtos não houvesse - a sua procura pelos Fenícios, ao longo de todo o curso do baixo Tejo, o qual atravessa 
as melhores terras de aptidão agropecuária do País. Com efeito, Aubet-SEMMLER (1991, p. 622) declara que as produções agropecuárias, nas zonas mais férteis dentre aquelas com que os Fenícios estabeleceram contacto, seriam suficientes para justificar a sua presença. No caso do Cerro del Vilar, Málaga, a ausência de recursos mineiros na região leva a "descartar, por conseguiente, la búsqueda $\mathrm{y}$ explotación de metales como uno de los móviles relacionados con las estrategias de control de recursos de los colonos fenicios del Guadalhorce. Por el contrario, una agricultura de regadío y, como complemento, la actividad ganadera bastarían por sí solas para justificar el origen de la colonia insular del Villar". No caso do Almaraz, encontraram-se, no enchimento da aludida fossa de detritos, abundantes restos de mamíferos, sendo predominantes, em termos de carne consumida, os grandes bovídeos, seguindo-se os ovinos/caprinos. A importância da bovinicultura foi já evidenciada em outros estabelecimentos fenícios da costa portuguesa (CARDOSO, 1993). Em compensação, os suídeos estão apenas presentes vestigialmente pelo javali. A ausência de porco doméstico pode ser indício de presença no local de populações semitas ou semitizadas, tal qual o verificado em outros contextos fenícios peninsulares como Toscanos, embora tal situação não possa ser tomada como regra, sem que antes se disponha de um conjunto mais significativo de elementos.

Ainda sobre a importância da criação de gado no baixo vale do Tejo, recorde-se a tão mencionada passagem de Terêncio Varrão (117 27 AC) e de Caio Plínio Segundo (23 - 69 DC), segundo a qual as éguas da Lusitânia, por serem tão velozes, concebiam do vento... alusão clara à excelência destes animais, que encontrariam nas vastas campinas de Ribatejo, então como na actualidade, as condições propícias à sua existência.

Entre as culturas salientava-se a da vinha, cuja importância se encontra evidenciada pelas análises polínicas correspondentes a sondagem efectuada em local adjacente ao Alto do Castelo, Alpiarça: cerca de 600 AC, observa-se, no diagrama polínico obtido, um pico de Vitis, cuja forma muito abrupta aponta para um cultivo intencional, confirmando-se, deste modo, a menção de Estrabão, embora reportando-se a alguns séculos mais tarde, de ser esta uma região "fértil e bem revestida de vinha “ (KALB \& HOCK, 1988, p. 199). A cultura da vinha - também documentada em Almaraz por grainhas - cuja introdução se costuma atribuir aos Fenícios, e a consequente produção 
vinícola, destinar-se-ia, sobretudo, à exportação, através da via fluvial, especialmente no trecho em que ela é facilmente navegável, pelo menos até Abrantes, por navios de pequeno calado. Tais embarcações fluviais - talvez do tipo das representadas em asses de Brutobriga, cerca de 50 AC - permitiam o imediato escoamento dos produtos, tanto os produzidos localmente, como os oriundos de regiões mais interiores, como o estanho das Beiras.

As feitorias de Almaraz e de Lisboa, implantadas estrategicamente de ambos os lados do estreitamento terminal do estuário, controlariam facilmente o comércio fluvial de e para o interior, isto sem prejuízo de também poderem servir de apoio à navegação atlântica de cabotagem, na busca do estanho das Cassitérides. Podemos ainda aceitar que a chegada dos Fenícios terá contribuído para a intensificação da produção dos produtos referidos - designadamente o vinho, a carne, as conservas de peixe, além de diversas indústrias extractivas, como o sal, o ouro e o estanho - por forma a se obterem excedentes susceptíveis de serem trocados por produtos manufacturados. A produção agropecuária e industrial teria, então, sido incrementada, fortalecendo a informação das elites que a controlavam (WAGNER, 1995, p. 110)

E que produtos eram esses?

No grupo das cerâmicas, avultam, como já se referiu a propósito do Almaraz, as ânforas, pythoi e cerâmicas finas, especialmente as de verniz vermelho, a maioria das quais poderia ser fabricada nas feitorias e colónias fenícias da região do estreito de Gibraltar ou da costa marroquina, o que explicaria a existência de tipos desconhecidos no Mediterrâneo oriental. As ânforas e outros grandes contentores, além de poderem ser utilizados para o transporte de preparados piscícolas, do azeite e do vinho, produzidos localmente, poderiam constituir unidades de troca, tal qual o verificado na costa andaluza (PELLICER, 1979/80, p. 329).

As cerâmicas cinzentas são outro grupo que importa referir. A elevada qualidade dos exemplares exumados em Almaraz - superiores, mesmo, às verdadeiras produções fenícias (CARDOSO, 1990) documenta o elevado nível técnico atingido por artífices locais ou regionais que, sediados ou não em estabelecimentos fenícios, promoviam o fabrico em série de recipientes mais ao gosto local.

No grupo dos produtos metálicos do quotidiano, são de destacar as fíbulas. São agora correntes as do tipo de "dupla mola", que vieram substituir as "de cotovelo", do final do Bronze Final, com larga distribuição por toda a área tartéssica e de colonização fenícia, cuja 
cronologia se centra no século VII AC (PELLICER, 1979/80, p. 330; AlmAGro-Gorbea, 1973; SCHUBART \& NIEMEYER, 1976, p. 226; Aubet-SeMmLER, 1989, p. 312). Os únicos exemplares até ao presente registados na região de Lisboa provêm de Freiria, Cascais (informação de Guilherme Cardoso, que agradecemos) e de Casais de Vila Chã, Amadora, este último pertencente ao tipo Schúle 2b (PONTE, 1982/83 b). Ainda em área interessada a este estudo, é de referir um outro exemplar, recolhido no povoado de altura e fortificado de Chibanes, Palmeia (COSTA, 1910).

No capítulo dos objectos metálicos de carácter litúrgico, é de destacar o oinochoe recolhido em uma sepultura perto de Torres Vedras, conjuntamente com as asas do respectivo "brasero" (TRINDADE \& FERREIRA, 1965), que, como é sabido corresponde à bacia de libação. Trata-se de produtos oriundos provavelmente da área tartéssica (GAMITO, 1988).Tal achado, que se inscreve no apogeu do comércio fenício, nos séculos VII/VI AC, vem mostrar que tal expansão foi acompanhada, por parte dos autóctones, ou ao menos, das suas "elites", da adopção de práticas religiosas exógenas, nas quais estes artefactos desempenhariam papel relevante. A presença de produtos sumptuários como este ilustra, por outro lado, a intensa interacção do importante foco civilizacional tartéssico, como uma região já então periférica. Trata-se de uma das melhores evidências de que poderíamos dispor para ilustrar a integração ideológica das "elites" locais, expressa pela adopção de novas crenças e práticas religiosas: corresponde a uma das três vias ou mecanismos sócio-políticos de interacção que habitualmente se observam na Antiguidade (AUBET-SEMMLER, 1990) e que, na fachada ocidental peninsular, asseguraram o sucesso da empresa fenícia, por pouco expressiva que o fenómeno da aculturação tenha sido na região em apreço, como em outras (AlARCãO, 1990); "La aculturación orientalizante se constituye en una estrategia no violenta de explotación colonial..." (WAGNER, 1995, p. I11)

$\mathrm{Na}$ segunda metade do século VI AC, assiste-se a profunda crise nos estabelecimentos fenícios do Ocidente, bem expressa pelo abandono de alguns deles, em pleno auge da sua actividade, como Toscanos ou o Cerro del Villar (Aubet-Semmler, 1990, p. 41). A explicação aduzida pela autora pressupõe uma evolução interna das características económico-sociais destas comunidades, com a deslocação dos centros económicos para zonas então periféricas, como o alto Guadalquivir. Outra é a interpretação de PELLICER (1979/80, p. $330,331)$. No decurso do século VI AC, a importação de cerâmicas orientais já não seria tão rentável, considerando a alta qualidade das 
produções locais, além disso melhor adaptadas às necessidades e preferências dos seus utilizadores. Por outro lado, a quebra de importações orientais - como bem demonstra o decréscimo de ânforas fenícias no decurso da segunda metade daquele século, no cerro Macareno - resultaria, entre outras circunstâncias, da queda de Tiro, em 576 AC. Esta explicação é rejeitada por Aubet-Semmler (1990, p. 41), considerando que "La caída de Tiro es muy anterior a los acontecimientos de finales del siglo VI". PEREIRA (1993, p. 300) avança com outra hipótese, atribuindo o declínio da presença fenícia no Ocidente à exaustão das minas de prata peninsulares as quais, para continuarem em exploração, necessitariam de tecnologias à data desconhecidas.

Outras explicações foram aduzidas para explicar o declínio brusco das importações fenícias peninsulares. GOMES (1992 b, p. 138) invoca a migração de povos de origem continental, ou a hostilidade de outros, habitando áreas menos privilegiadas, como estando na origem do desaparecimento da brilhante cultura orientalizante do litoral meridional peninsular, no que também é contestado, antecipadamente, por Aubet-Semmler (1990, p. 41), declarando que não se entrevêem provas arqueológicas de tais movimentações étnicas. GOMES (op. cit.) invoca, ainda, a derrota dos Tartéssicos, aliados aos gregos focenses, na batalha naval de Alalia, Córsega, em 535 AC, como estando na origem do poderio cartaginês na Península Ibérica. Contudo, segundo FABIÃO (1993, p. 165), em tal confronto"não parece ter estado em causa qualquer tentativa de controle do tráfego marítimo para ocidente, como por vezes alguns têm defendido". O mesmo autor adianta (p. 128) outras explicações; o excesso da oferta da prata peninsular teria conduzido à quebra do seu valor comercial, provocando, pela sobrevalorização de outros produtos, uma crise económico-social, de que teria resultado a decadência de Tiro. Dela decorreria o abandono dos estabelecimentos tirios peninsulares, bem como o desaparecimento do reino de Tartesso, devido aos laços de dependência económica estabelecidos com aqueles.

Por crise interna, ou mais provavelmente pela conjunção de diversas causas, o certo é que o fim da brilhante cultura orientalizante tartéssica, concomitante com o da presença fenícia, que constituiu o estímulo indispensável para a sua formação e plena afirmação, mantém-se como uma das questões ainda por esclarecer (AUBET-SEMMLER, 1990, p. 42). 
$\mathrm{Na}$ região de Lisboa, tais factos têm, como não podia deixar de ser, expressão ao nível do registo arqueológico. Por um lado, encontra-se bem documentada a referida ruptura do abastecimento fenício, pelo desaparecimento de um dos elementos mais característicos: a cerâmica de verniz vermelho orientalizante, cuja presença cessa no final do século VI AC. Por outro lado, aos materiais característicos de uma I Idade do Ferro orientalizante, sucedem-se, no século V AC - limite inferior "clássico" da II Idade do Ferro, coincidente com a chegada dos Celtas, ao Sudoeste peninsular - outros, ainda pior conhecidos, embora marcados por nítidas influências mediterrâneas, ou púnicas, que persistem, em nítida continuidade com as anteriores. Tal situação encontra-se exemplarmente exposta no corte estratigráfico registado no castelo de Alcácer do Sal, a cujas camadas da I Idade do Ferro se sucedem outras, que contêm materiais de uma II Idade do Ferro, mantendo as características mediterrâneas (SILVA et al, 1980/81); não é lícito considerar qualquer descontinuidade na ocupação, muito menos de ordem étnica ou cultural.

Os elementos disponíveis para a região de Lisboa configuram, igualmente, uma continuidade da presença directa ou influência material de povos mediterrâneos. Prova disso é a dificuldade em separar produções da segunda metade do século VI das do século seguinte.

Às importações fenícias e respectivas imitações, dos séculos VII e VI AC, sucedem-se materiais de produção púnica, também eles mesclados com produções locais ou regionais. Os testemunhos recuperados demonstram a continuidade das relações comerciais desta área com o mundo mediterrâneo. Entre eles, avultam os materiais provenientes do subsolo da baixa lisboeta. Os primeiros a serem identificados, no início do século, por Vergilio Correia, provêm da rua dos Douradores (CARDOSO \& CARREIRA, 1993) e podem ainda inscrever-se no mundo fenício da primeira metade do século VI AC, sendo, desta forma, coevos dos restos exumados na plataforma da Sé e que constam da referida publicação. Os materiais e estruturas recentemente exumados nas escavações das fundações da sucursal do Banco Comercial Português da Rua Augusta, mais tardios, documentam, como o verificado na Sé, a nítida continuidade de ocupação da zona baixa da actual cidade. Da publicação preliminar dos notáveis trabalhos arqueológicos ali realizados, dirigidos por C. Amaro, avultam as produções ibero-púnicas, onde se evidencia um 
suporte de ânfora, de forma anelar, com duas marcas zoomórficas impressas; trata-se, evidentemente, de uma peça de origem púnica. O conjunto sugere cronologia centrada no século IV AC, embora algumas peças remontem ao $\mathrm{V}$ e outras atinjam o III AC (AMARO, 1995). Evidencia-se, deste modo, continuidade funcional do sítio de Lisboa, do século VII até pelo menos o século III AC; enquanto a encosta da Sé era ocupada, ao longo de todo este período, pela zona residencial, na parte baixa situava-se a zona portuária, ao longo da margem esquerda de antiga enseada e junto da sua confluência com o estuário.

Um fragmento de cerâmica ática daqui proveniente é datável no século IV AC, tal como dois outros, recolhidos no Almaraz. Tais exemplares demonstram a difusão de produtos cerâmicos de luxo, talvez a partir do importante foco comercial púnico de Gades. A importância do comércio marítimo, responsável pela chegada de tais materiais ao estuário do Tejo, encontra-se expressivamente registada por desenho, feito na pasta fresca, de um fragmento de provável prato, de uma silhueta de nave de comércio fenício-púnica, munida de dois lemes laterais à ré (AMARO, 1995, p. 11).

Porém, não é apenas nos artefactos recolhidos que as influências mediterrâneas se afirmam. As estruturas de planta rectangular, que então se desenvolveriam ao longo da praia arenosa, reforçam-nas. Trata-se de habitações e talvez de armazéns, possuindo por vezes lareiras de grandes seixos de quartzito, de contorno circular, inexistentes no local, mas abundantes nos terraços plistocénicos da margem esquerda do Tejo, mais para montante, o que é uma prova adicional da intensa navegação fluvial, em que tais materiais poderiam desempenhar as funções de lastro. Os muros destas construções eram constituídos por blocos de calcário conquífero do Miocènico, disponíveis na zona, cuidadosamente dispostos e argamassados com barro. A regularidade do topo, que não ultrapassa $40 \mathrm{~cm}$ de altura, leva a considerar tais muretes como o embasamento de paredes que se desenvolveriam superiormente por blocos de argila ou taipa. Foi, aliás este argumento que conduziu ROCHA (1905/1908, p. 316) a idêntica conclusão sobre as habitações por ele exumadas em Santa Olaia, em tudo semelhantes a estas. As coberturas das casas do subsolo lisboeta, tal como ali, seriam de colmo, cobertas de argila, conforme vestígios encontrados pela recente investigadora da estação (PEREIRA, 1993, p. 290). Assim se poderá interpretar o fragmento exumado de cerâmica de revestimento com impressões de cana (AMARO, 1995, p. 12). 
O carácter comercial, e também industrial, do conjunto é ilustrado pela presença de um pequeno forno de caldeira circular, sobreposto a uma das habitações anteriormente referida, sendo-lhe, desta forma, pouco posterior. Os materiais recolhidos no seu interior correspondem a momento imediatamente ulterior ao seu abandono - não podendo, pois, relacionar-se com a sua actividade - são característicamente púnicos. Avultam ânforas com asas convexo-côncavas, com aguada branca na superfície externa. A actividade deste forno, atendendo às suas pequenas dimensões, não poderá estar relacionada com o fabrico de recipientes para a indústria de preparados piscícolas, destinados à exportação, antecessora daquela que, no Período Romano, se viria a instalar no mesmo local.

A presença púnica encontra-se, pois, bem comprovada no próprio subsolo de Lisboa, podendo considerar-se como extensão ocidental do comércio mediterrâneo - espaço cultural de que fazia - até pela sua posição geográfica - parte integrante. Pelo seu porto continuariam a ser escoados os produtos produzidos ou transportados ao longo do baixo Tejo, além daqueles directamente provenientes do "hinterland", como se vinha praticando desde os primórdios da Idade do Ferro.

$\mathrm{Na}$ adjacência da cidade comercial espraiavam-se, pelos férteis campos agrícolas, numerosas "granjas" ou "casais agrícolas", sucedâneas das suas homólogas do Bronze Final, documentando a continuidade do povoamento disperso e de pendor agropastoril desta região: pode concluir-se que as novas tecnologias trazidas pelos Fenícios, designadamente a possibilidade de produção de cerâmicas em série, mediante a introdução do torno rápido, ou a melhoria dos níveis de produção agrícola, decorrente da adopção de utensílios de ferro, não se repercutiram de forma evidente na estrutura económico-social destas comunidades.

A estratificação social, já bem evidente no fim do Bronze Final, embora ainda não tendo talvez expressão numa hierarquização dos povoados de altura, acentua-se no decurso da I Idade do Ferro, com a possível emergência de um poder de carácter hereditário sediado em lugares que, mercê do desenvolvimento que auferiram com o comércio fenício, se assumiram, então, como verdadeiros "lugares centrais". A emergência de Olisipo, a “enseada amena" dos Fenícios, poderá corresponder a essa realidade. Trata-se de um processo que, embora não possa ser cabalmente demonstrado na área de Lisboa, por escassez de elementos, corresponde ao que foi verificado noutras regiões arqueológicamente mais bem conhecidas. 
Os espólios exumados nos pequenos núcleos rurais situados no território adjacente, como o dos moinhos da Atalaia, Amadora e Outurela I e Outurela II, Oeiras, denunciam o vigor da presença mediterrânea que se continuou a fazer sentir, desde o final do século VI, e no decurso de todo o século $\mathrm{V}$ AC, a partir do foco difusor situado em Lisboa. Embora correspondam a pequenos locais de encosta, alguns assumem maiores dimensões, situando-se a cotas mais elevadas, mas não defendidos. É o caso do povoado de Santa Eufémia, Sintra (MARQUES, 1982/83). A presença de ânforas na tradição ou afins da F. R. 1, associadas a outras, da forma Mañá/Pascual A4, sugerem a referida cronologia. Este povoado dominava uma extensa e fértil planície, onde a agricultura poderia ser intensiva.

As cerâmicas exumadas nestas estações - de onde estão ausentes as de verniz vermelho - caracterizam-se pela permanência de formas de tradição fenícia, como ânforas e pythoi - estando ausentes as asas de duplo rolo - e urnas, recipientes por vezes pintados com bandas brancas e vermelhas, sobre superfícies por vezes engobadas de branco, acompanhadas de uma grande quantidade de cerâmicas de fabrico ao torno rápido local ou regional e de onde estão quase ausentes as cerâmicas de fabrico manual, embora estas possam, nalguns casos, ter coexistido com produções mediterrâneas, como se verificou no povoado de Pedrada, Almada (SILVA \& SOARES, 1986, Fig. 105); as cerâmicas cinzentas estão representadas por exemplares afins dos Grupos A e B de Alcácer do Sal (SILVA et al, 1980/81).

As estações de Outurela I e Outurela II correspondem a uma única ocupação de carácter habitacional e por certo durante um curto período de tempo, o que confere ao espólio exumado uma coerência interna do maior interesse. As cerâmicas cinzentas do Grupo A, em Alcácer do Sal, coexistem com as do grupo B, embora denotando uma evolução percentual inversa, até ao domínio romano. Segundo os autores, é provável que o Grupo A se tenha prolongado artificialmente no tempo, por revolvimentos verificados na estação: "este tipo de cerâmica deixa de ter expressão nos estratos posteriores ao século $\mathrm{V}$ nas numerosas jazidas do sul de Espanha, onde tem sido identificada" (SILVA et al, 1980/81, p. 179). Tal afirmação confere um limite inferior à ocupação de Outurela I e Outurela II, o final do século V AC, como já anteriormente havia sido proposto (CARDOSO, 1990). Segundo opinião de C. Tavares da Silva, que agradecemos, os materiais por ele observados daquelas duas estações inscrevem-se nos finais do século 
VI ou no século seguinte. Além das cerâmicas cinzentas referidas, ocorre um outro grupo com características específicas: trata-se de recipientes de formas diversas (jarros, pratos, taças, vasos de carena alta, etc), de pastas muito finas, cinzentas a negras, e com acabamento superficial brilhante, de toque metálico, obtido por brunimento. Alguns exemplares parecem situar-se na descendência directa de formas da Idade do Bronze, hipótese reforçada tanto pela coloração das superfícies, como pelo respectivo acabamento. Trata-se de grupo presente na região de Lisboa (PINTO \& PARREIRA, 1978; CARDOSO, 1990), em Conimbriga (AlarCÃo, 1974; CorReia, 1993) e em Santa Olaia (ROCHA, 1905/08), mas ausente no vale do Sado (Setúbal, Abul, Alcácer do Sal), facto que the confere cunho regional, de momento limitado ao norte do Tejo. Tal conclusão é apoiada pelo facto de se saber que o fabrico de cerâmicas cinzentas era independente, mesmo em povoados próximos, como Conimbriga e Santa Olaia ( in CORREIA, 1993)

Nos moinhos da Atalaia, Amadora, estação com espólio muito idêntico, a ocupação sidérica foi situada nos século V/IV AC (PINTO \& PARREIRA, 1977, p. 152), ainda que com evidentes reminiscências fenícias, como documenta a ânfora de tradição ou afim da F. R. 1, também presente em Outurela I e Outurela II. Nesta estação recolheu-se uma fíbula anular idêntica a exemplar de Outurela I e também a outra, recuperada na baixa lisboeta e atribuída ao século IV AC (AMARo, 1995). A tipologia da fíbula de Outurela I é compatível com a cronologia anteriormente proposta para a estação, sendo o exemplar de Lisboa nitidamente mais moderno.

As estruturas habitacionais identificadas em Outurela I e Outurela II (CARDOSO, 1987, 1990) correspondem a casas de planta rectangular, de tipologia e técnica construtiva em tudo idênticas às da baixa lisboeta, de Santa Olaia e de Alcácer do Sal, com cronologias extremas dos séculos VII ao IV AC. O embasamento é de alvenaria, como naqueles casos, sendo aqui constituído por blocos basálticos não aparelhados, disponíveis localmente. Verifica-se, pois, a manutenção da arquitectura mediterrânea, em tudo coerente com a tipologia dos materiais exumados, por um largo período de tempo. Acessoriamente, observamse zonas lajeadas, como em Outurela I ou na pequena casa de planta rectangular de Rei Mouro, Sintra (SERRÃO, 1980).

A substituição de casas de planta oval, típicas do Bronze Final da região, como a da Tapada da Ajuda, por habitações de planta 
rectangular, na Idade do Ferro, é uma das evidências mais interessantes da evolução material destas comunidades da região de Lisboa, com paralelos muito próximos no Baixo Alentejo. Aqui, as duas casas ovais do povoado de Neves II, Castro Verde, dão lugar, no mesmo local, a casas de planta rectangular da Idade do Ferro, idênticas às de Outurela I e Outurela II, ou das exumadas na baixa lisboeta (MAIA \& MAIA, 1986). Tais casas terão antecedentes mais antigos na mesma região, corporizados pelos exemplos reconhecidos em várias estações dos concelhos de Castro Verde, Almodovar e Ourique (BEIRÃO, 1986). O seu carácter mediterrâneo é irrecusável, sendo reforçado pelos espólios encontrados, tal como se verificou na área de Lisboa. A estratégia de povoamento por elas documentada é também idêntica; tais habitações corresponderiam a pequenas comunidades, de raiz familiar, dispersas por toda uma vasta região, de economia marcadamente agropastoril. A pobreza dos espólios exumados sugere, porém, o deficit agrícola da região, onde a ocorrência de algumas peças aparentemente sumptuárias nas necrópoles correspondentes, mais não são que produtos fabricados em série e massivamente difundidos pelos Fenícios, os quais não deverão iludir-nos quanto ao verdadeiro estatuto económico dos respectivos possuidores (FABĨ̃O, 1993).

A preponderância do comércio púnico, verificada na área de Lisboa no decurso da II Idade do Ferro e, de uma maneira mais alargada, em todo o baixo Tejo, do qual fazia parte integrante, encontrase expressivamente documentada por numismas hispano-cartagineses do último quartel do século III AC (FARIA, 1987), um proveniente do castro de Curvaceiras, Alenquer, outro recolhido nas escavações efectuadas no Cabeço da Bruxa, Alpiarça (KALB \& HOCK, 1981/82, Est. XIII, $\left.\mathrm{n}^{\circ} .5,6\right)$. Com efeito, as cerâmicas estampilhadas da II Idade do Ferro, a que se atribuem origens continentais, da Meseta central (ARNAUD \& GAMITO, 1974/77) estão, de facto, quase ausentes desta região, como seria lógico em áreas fortemente marcadas pelo comércio mediterrâneo. Ocorrem apenas escassos exemplares, de diversas épocas, dois na Lapa do Fumo e outros no castro de Chibanes, Palmeia (Costa, 1910, Est. Ill e IV); um único fragmento recolhido em Alcácer do Sal, atribuído aos séculos III/II AC (DlOGO \& FARIA, 1987), explica-se, como os anteriores, por intercâmbios comerciais de carácter transregional (FABIÃO, 1993), e não pela presença directa das populações célticas continentais, que fabricavam tais recipientes, aliás desmentida pela própria escassez de tais materiais. 
Em trabalho recente (ARRUDA et al., 1995) defende-se a marcada influência mediterrânea que, sem soluções de continuidade, teria dominado toda a II Idade do Ferro do Sul de Portugal. A situação exposta para a região de Lisboa confirma plenamente aquela realidade.

Na margem sul do Tejo, à transição da I para a II Idade do Ferro pertencerão, igualmente, pequenas estruturas de carácter agropecuário, idênticas às da margem norte. Os materiais exumados, ainda inéditos, indicam a sua filiação clara no mesmo mundo comercial, de raiz púnica. É o caso dos recolhidos por equipa do Centro de Arqueologia de Almada em terrenos da Faculdade de Ciências e Tecnologia da UNL, no Monte de Caparica (CARDOSO, no prelo, b). Trata-se de sítio de relevo muito suave, aplanado, pertencente a plataforma que culmina os relevos da margem sul, muito semelhantes aos da margem norte, não fosse a sua menor aptidão agrícola, que justifica também a menor densidade da sua ocupação. O espólio integra numerosos fragmentos de ânforas, estando igualmente presentes cerâmicas cinzentas.

Desconhecem-se quase completamente testemunhos sepulcrais do período entre o século $\mathrm{V}$ e finais do III $\mathrm{AC}$, na região de Lisboa. Exceptua-se a necrópole do Casalão, Sesimbra (SERRÃO, 1964), na qual se escavaram cinco sepulturas de inumação individuais, correspondendo a caixas rectangulares definidas por lajes. O espólio exumado não deixou dúvidas ao seu explorador quanto à integração da necrópole na II Idade do Ferro, a qual veio a ser recentemente confirmada pelo radiocarbono, tendo-se obtido a data de $2290 \pm 40 \mathrm{BP}$ (SERRÃO, 1994, p. 58).

Tal facto mostra que a prática da incineração coexistiria com a da inumação, no sul do País, no decurso da Idade do Ferro, ao menos na sua orla costeira, sendo explicável pela existência de tradições culturais específicas. A referida coexistência foi observada por vezes em uma mesma necrópole, como em Mealha Nova ou Cerro do Ouro, Ourique (in FABIÃO, 1993, p. 136). Talvez que a esta época se possa também reportar a sepultura do mesmo tipo, acidentalmente descoberta no século passado, na Tapada da Ajuda (SILVA, 1879); porém, os elementos disponíveis são insuficientes para se lhe atribuir cronologia definida.

Na região de Lisboa, os derradeiros momentos da Idade do Ferro revelam, tal como os antecedentes, marcadas características mediterrâneas, afirmando-se em evidente continuidade com aqueles. 
Consubstanciam uma III Idade do Ferro, segundo o critério adoptado em Alcácer do Sal: o estratótipo para este período pode encontrar-se no corte publicado (SILVA et ai, 1980/81), corporizando a Fase V de ocupação do sitio, entre os séculos $\mathrm{Hela}$. C. Tal fase é marcada pela chegada de materiais romanos, que se juntam às produções púnicas.

Sem se pretender entrar na abordagem do dominio romano, são de mencionar achados de ânforas neo-púnicas, últimas produções de uma tradição anfórica que remonta ao século VIII AC: as numerosas asas anulares, de secção circular, de ânforas que ocorrem nestas estações, mantêm-se inalteradas desde a época fenícia até aos inícios do século I AC, tal como na Andalusia (PELLICER, 1978), então já plenamente coevas de fabricos itálicos, aos quais, por vezes, surgem associados. $\mathrm{Na}$ região de Lisboa, reconheceram-se fragmentos de ânforas da forma Dressel 18, Mañá C2 no Casal Cabanas, Sintra (MAIA, 1978, Est. Ill, Fig. 7; Pimenta, 1982/83, Est. I, n. 2 e 3) e na zona de Oeiras (CARDOSO, no preio a). Esta ânfora, segundo COELHO-SOARES (1986) que inventaria as ocorrências conhecidas em território português, serviria para o transporte de preparados piscícolas, conhecendo uma grande difusão por todo o Mediterrâneo ocidental, de meados do século II AC, até ao século seguinte, a partir de olarias norte-africanas.

Certas estações, como Freiría, são exemplo de notáveis permanências, até à plena Romanização, de pequenas comunidades que faziam da agricultura a sua actividade principal; com efeito, ali, encontra-se documentada uma prolongada ocupação da Idade do Ferro, que terá começado no século VII/VI AC, como sugere uma conta de pasta vítrea oculada (ENCARNAÇÃO, 1994, p. 204). Da mesma forma, em Areia, Cascais, que depois viria a tornar-se um importante núcleo romano, foi recolhido o arco de uma fíbula da I Idade do Ferro (PONTE, 1982/83 b), que acompanhava outros materiais sidéricos; de referir ainda a recolha, no nível subjacente às construções da villa de Freiría, de um asse de Salacia, com a legenda IMP SAL (informação de G. Cardoso, que se agradece), topónimo que substituiu o nome indígena, cerca de 54/44 AC, em honra de Sexto Pompeio (FARIA, 1989, p. 79).

Neste intenso comércio ao longo do litoral mediterrâneo e atlântico, sítios mais majestosos assumiriam especial importância na navegação. Por isso, ficaram assinalados pela construção de templos, alguns por certo de fundação pré-histórica. Um dos raros casos em que terá sido possível documentar uma dessas situações situa-se no litoral da serra de Sintra, no Espigão das Ruivas, Cascais, rochedo isolado em 
forma de abrupto promontório. As escavações permitiram recuperar materiais da Idade do Ferro de várias épocas e romanos (CARDOSO, 1991, p. 31; CARDOSO \& ENCARNAÇÃO, 1992), talvez relacionados, segundo os autores, com um templo associado ao culto de Poseidon, ou da Lua, como sugere o topónimo de "Porto Touro". Com efeito, o achado de cepos de âncora na Berlenga, cujos restos de madeira conservados na "alma" depois de datados pelo radiocarbono, indicam os séculos V/IV cal AC - os mais antigos que se dataram até o presente (ALVES, 1993) - vem materializar tais navegações.

Outro templo, talvez de fundação pré-romana, situado sobre o mar, no Alto da Vigia, Praia das Maçãs, Sintra, era consagrado ao Sol e à Lua (RIBEIRO, 1982/83), tal como outros que se dispersariam por toda a serra de Sintra, na verdade toda ela uma montanha sagrada (idem, ibidem). O culto de divindades aquáticas, especialmente patente naquela região no decurso do Período Romano (RIBEIRO, 1983), teria, igualmente, raízes anteriores, que não custa fazer remontar à Idade do Bronze.

São, com efeito, escassas outras provas documentais, na região em apreço, de práticas litúrgicas sidéricas. Uma delas consiste em uma pequena figura de carneiro (FERREIRA \& FrANÇA, 1954; PONTE, 1982/83 a) ou de cavalo (GOMES, 1986), de bronze, fundida em molde, recolhida junto da vila de Sintra. GOMES (1986) inventaria, na região sul do País, cerca de vinte estatuetas zoomórficas, predominando largamente (cerca de 50\%) as representações de cabras; de carneiro, reconheceu duas e apenas uma de cavalo. O exemplar de Sintra é difícil de datar, atendendo à conhecida sobrevivência estilística de tais representações (PONTE, 1982/83 a), dificuldade acrescida nos exemplares mais estilizados, como este. De qualquer modo, integrar-se-á na II Idade do Ferro, altura em que se assistiu à vulgarização de santuários rupestres ou campestres, a partir da segunda metade do século IV AC (GOMES, 1986). Outra finalidade possível para a peça em causa poderia ser a de integrar adereço mais complexo, como parece sugerir um possível embasamento, ligando as patas dianteiras do animal. Com efeito, as peças usadas independentemente, como exvotos, assentavam directamente pelas extremidades dos membros (GOMES, 1986).

Seja como for, e na hipótese de tal peça representar um carneiro (como parecem sugerir as suas características, demasiado diferentes das do cavalo representado por VASCONCELOS, 1920), poderia 
relacionar-se com o culto de Atégina, o qual abrangia parte da Lusitânia e da Bética (Vasconcelos, in PONTE, 1982/83 a).

Outro testemunho material que importa referir, no âmbito da análise de vestígios litúrgicos da região de Lisboa da Idade do Ferro, é o petroglifo de Magoito (SOUSA, 1990), o qual poderá ser, contudo, ainda do Bronze Final (informação de Mário Varela Gomes, que agradecemos). A representação principal consta de um orante, gravado na rocha branda.

Os testemunhos materiais, cuja caracterização e interpretação constituiu o objecto este estudo, e especialmente os de carácter habitacional, sugerem que as condições económico-sociais das comunidades que habitavam a região ribeirinha do estuário do Tejo, não se terão modificado sensivelmente desde o Bronze Final. E nítida a continuidade quanto à estratégia de ocupação e de aproveitamento dos recursos, de carácter exclusivamente agropastoril, que constituíam a sua principal fonte económica, verificada neste prolongado lapso de tempo.

A identidade cultural de tais populações, durante mais de um milénio, do Bronze Final à plena romanização é, também, um notável exemplo de continuidade, constituindo um raro exemplo de aculturação de populações de uma área periférica face aos grandes estímulos e impulsos civilizacionais meridionais que marcaram todo o I milénio AC. A evolução retratada a traços largos neste largo intervalo cronológico é comparável, deste modo, à conhecida em outras regiões peninsulares, como a Estremadura espanhola (ALMAGRo-GorBEA, 1990 , p. 110), então também ela uma região periférica face ao grande polo civilizacional que fora a área tartéssica.

\section{BIBLIOGRAFIA}

ALARCÃO, J. de ( 1974) - Cerâmica comum local e regional de Conimbriga.

Suplemento de Biblos, 8, 211 p. Coimbra.

AlarCÃO, J. de (1990) - Recensão bibliográfica. Conimbriga, 29, p. 149-153.

AlARCÃO, J. de (1992) - As estradas romanas de Portugal. Cuadernos de San Benito, 3, p. 69-75. Fundación San Benito de Alcántara. Madrid.

Alarcão, J.; Delgado, M.; Mayet, F.; Alarcão, A. M. \& Ponte, S. da (1976) -

Fouilles de Conimbriga. VI - Céramiques diverses et verres, p. 3 - 17. Diffusion De Boccard. Paris.

Almagro-GorbeA, M. (1973) - El Bronce Final y el inicio de la Edad del Hierro en

la Meseta sur. Publicación en extracto de Tesis Doctoral. Universidad Complutense. Madrid. 
Almagro-GorbeA, M. (1990) - El Periodo Orientalizante en Extremadura. In La Cultura Tartesica y Extremadura. Cuadernos Emeritenses, 2, p. 85-125.

Alves, F. J. S. (1993) - Typologie et chronologie des jas d'ancre en plomb découverts dans les eaux portugaises. Mediterrâneo, 2, p. 311-328.

AMARO, C. (1993) - Vestígios materiais orientalizantes do claustro de Sé de Lisboa. Estudos Orientais, 4, p. 183-192.

AMARO, C. (1995) - Núcleo arqueológico da rua dos Correeiros. Fundação Banco Comercial Português. Lisboa.

Armbruster, B. (1995) - O colar de Sintra. In A Idade do Bronze em Portugal, p. 103. Instituto Português de Museus. Lisboa.

ARnAud, J. M. \& GAMito, T. J. (1974/77) - Cerâmicas estampilhadas da Idade do Ferro do sul de Portugal. 1- Cabeça de Vaiamonte - Monforte. o Arqueólogo Português, S. III, 7/9, p. 165-202.

Arnaud, J. M.; Oliveira, V. S. \& Jorge, V. de O. (1971) - O povoado fortificado neo- e eneolítico do Penedo de Lexim (Mafra). O Arqueólogo Português, S. III, 5, p. 97-131.

Arteaga, O.; Hoffmann, G.; Schubart, H. \& Schultz, H. D. (1988) - Geologische-archeologische Forschungen zum Verlauf der andalusischen Mittelmeerküst. Madrider Beiträge, Band 14, p. 107-126.

ArrudA, A. M. (1993) - A ocupação da Idade do Ferro da alcáçova de Santarém no contexto da expansão fenícia para a fachada atlântica peninsular. Estudos Orientais, 4, p. 193-214.

ArrudA, A. M.; Guerra, A. \& FABIÃo, C. (1995) - O que é a II Idade do Ferro no Sul de Portugal?. Trabalhos de Antropologia e Etnologia, 35 (2), p. 237-257.

Aubet-Semmler, M. E. (1990) - EI impacto fenicio en el interior del mediodía peninsular. In La Cultura Tartesica y Extremadura. Cuadernos Emeritenses, 2, p. 29-44.

AUBET, M. E. (1994) - Tiro y las colonias fenicias de Occidente. Edición ampliada y puesta al día. Crítica. Barcelona.

Aubet-Semmler, M. E. (1989, coord.) - Tartessos. Arqueologia protohistorica del Bajo Guadalquivir. Ausa. Sabadell.

Aubet-Semmler, M. E. (1991) - Notas sobre las colonias del Sur de España y su función en el marco territorial: el ejemplo del Cerro del Villar (Málaga). Atti del II Congresso Internazionale di Studi Fenici e Punici, 2, p. 617-626. Consiglio Nazionale delle Richerche. Roma.

Barros, L. de; CArdoso, J. L. \& SAbrosA, A. (1993) - Fenícios na margem sul do Tejo. Economia e integração cultural do povoado do Almaraz - Almada. Estudos Orientais, 4, p. 143-181.

BEIRÃO, C: M. M. (1986) - Une civilisation protohistorique du sud du Portugal (I Age du Fer). Diffusion De Boccard. Paris.

BelÉN, M.; Amo, M. del \& FERnÁNDEZ-MiRANDA, M. (1982) - Secuencia cultural del poblamiento en la actual ciudad de Huelva durante los siglos IX-VI a. C. Huelva Arqueológica, 6, p. 21-39.

CARdoso, G. (1991) - Carta arqueológica do concelho de Cascais. Câmara Municipal de Cascais.

Conimbriga, 34 (1995), 33-74 
CARdoso, J. L. (1987) - No estuário do Tejo, do Paleolítico à Idade do Ferro. In Arqueologia no vale do Tejo. IPPC/DA. Lisboa.

CARdoso, J. L. (1990) - A presença oriental no povoamento da I Idade do Ferro na região ribeirinha do estuário do Tejo. Estudos Orientais, 1, p. 119-134.

CARdoso, J. L. (1993) - Contribuição para o conhecimento da alimentação em contexto fenício. Estudo dos restos da Rocha Branca (Silves). Estudos Orientais, 4, p. 109-126.

CARdoso, J. L. (1994 a) - Comentário ao sítio arqueológico da Tapada da Ajuda. In Lisboa Subterrânea, p. 192-193. Instituto Português de Museus. Lisboa.

CARdoso, J. L. (1994 b) - Comentário ao sítio arqueológico de Outurela (Oeiras). In Lisboa Subterrânea, p. 206. Instituto Português de Museus. Lisboa.

CARDoso, J. L. (1994 c) - Investigação arqueológica na área de Lisboa. Os últimos dez anos. Al-Madan, S. II, 3, p. 59-74.

CARDoso, J. L. (1995 a) - Ocupação campaniforme do povoado de Montes Claros. In A Idade do Bronze em Portugal, p. 35. Instituto Português de Museus. Lisboa.

CARdoso, J. L. (1995 b) - O povoado do Bronze Final da Tapada da Ajuda. In A Idade do Bronze em Portugal, p. 48. Instituto Português de Museus. Lisboa.

Cardoso, J. L. (1995 c) - Os povoados do Bronze Final a Norte do estuário do Tejo. In A Idade do Bronze em Portugal, p.126. Instituto Português de Museus. Lisboa.

CARDoso, J. L. (1995 d) - As cerâmicas de ornatos brunidos da Lapa do Fumo. In A Idade do Bronze em Portugal, p. 88. Instituto Português de Museus. Lisboa.

CARDoso, J. L. (no prelo a) - A III Idade do Ferro no concelho de Oeiras: um contributo. Estudos Arqueológicos de Oeiras, 6.

CArdoso, J. L. (no prelo b) - Ocupação da Idade do Ferro do campus da Faculdade de Ciências e Tecnologia da Universidade Nova de Lisboa (Monte de Caparica). Al-Madan, 5.

CARdoso, J. L. (no prelo c) - Cerâmicas de ornatos brunidos da gruta do Correio-Mor (Loures). Estudos Arqueológicos de Oeiras, 6.

CARDoso, J. L. (no prelo d) - Duas casas de época campaniforme de Leceia. Trabalhos de Arqueologia da EAM, 4. Colibri. Lisboa.

CARDoso, J. L. (em preparação) - A ocupação do Bronze Final do Castelo dos Mouros (Sintra).

Cardoso, J. L.. \& CARdoso, G. (em preparação) - O povoado da Idade do Bronze do Cabeço do Mouro.

CARdoso, G. \& EnCARnAÇÃO, J. d'(1992) - Sondagem no Espigão das Ruivas (Alcabideche, Cascais). Al-Madan, S. II, 2, p. 150.

Cardoso, J. L. \& CARreira, J. R. (1993) - Le Bronze Final et le début de l'Âge du Fer dans la région riveraine de l'estuaire du Tage. Mediterrâneo, 2, p. 193-206.

Cardoso, J. L.; Roque, J.; Peixoto, F. \& Freitas, F. (1980/81) - Descoberta de jazida da Idade do Bronze na Tapada da Ajuda. Setúbal Arqueológica, 6/7, p. 117-138.

Cardoso, J. L.; Rodrigues, J. S.; Monjardino, J. \& Carreira, J. R. (1986) A jazida do Bronze Final da Tapada da Ajuda. Lisboa. Revista Municipal, S. II, 15 , p. 13-18.

Conimbriga, 34 (1995), 33-74 
Cardoso, J. L.; Guerra, M. F. \& GIL, F. B. (1992) - O depósito do Bronze Final de Alqueva e a tipologia das lanças do Bronze Final português. Mediterrâneo, 1, p. 231-252.

CARreIRA, J. R. (1994) - A Pré-história recente do abrigo grande das Bocas (Rio Maior). Trabalhos de Arqueologia da EAM, 2, p. 47-144. Colibri. Lisboa.

CARTAILHAC, E. (1886) - Les Âges préhistoriques de T Espagne et du Portugal C. Reinwald. Paris.

Choffat, P. (1912/13) - Sur les sables aurifères, marins, d'Adiça et sur d'autres dépôts aurifères de la côte occidentale de la péninsule de Setubal. Comunic. Serv. Geol. Port., 9, p. 5-26.

COElHO-SoARES, A. (1986) - Achados arqueológicos na vila de Odemira. Trabalhos de Arqueologia do Sul, 1, p. 87-92.

COFFYN, A. \& SION, H. (1993) - Les relations atlanto-méditerranéennes. Eléments pour une révision chronologique du Bronze final atlantique. Mediterraneo, 2, p. 285-310.

CorreiA, V. H. (1993) - Os mateririais pré-romanos de Conímbriga e a presença fenícia no baixo vale do Mondego. Estudos Orientais, 4, p. 229-283.

CostA, A. I. M. da (1910) - Estações prehistóricas dos arredores de Setubal. Appendice. Homem protohistorico. Idades do Bronze e do Ferro no castro de Chibanes. O Arqueólogo Português, 15, p. 55-83.

Cruz, J. C. M. de la (1990) - Die erste mykenische Keramik von der Iberischen Halbinsel. Praehistorische Zeitschrift, 65, p. 49-61. Berlin, New York.

Diogo, A. M. D. (1993) - Ânforas pré-romanas dos Chões de Alpompé (Santarém). Estudos Orientais, 4, p. 215-227.

Diogo, A. M. D. \& FARIA, J. C. L. (1987) - Cerâmica estampilhada da Idade do Ferro, proveniente de Alcácer do Sal. Arqueologia, 16, p. 95-96.

ENCARNAÇÃO, J. d'(1994) - "Conta de colar”. In Lisboa Subterrânea, p. 204. Instituto Português de Museus. Lisboa.

FABIÃO, C. (1993) - O passado proto-histórico e romano. In História de Portugal (dir. J. Mattoso), 1, p. 77-229. Ed. Estampa. Lisboa.

FARIA, A. M. de (1987) - Guerras e conflitos no vale do Tejo na antiguidade: o testemunho dos tesouros monetários. In Arqueologia no vale do Tejo, p. 60-61. IPPC/DA. Lisboa.

FARIA, A. M. de (1989) - A numária de Cantnipo. Conimbriga, 28, p. 71-99.

FERnÁndeZ-MANZANO, J. (1984) - Armas y utiles metálicos del Bronce final en la Meseta norte. Studia Archaeologica, 14, p. 5. Univ. Valladolid.

FerreirA, O. da V. \& FranÇA, J. C. (1954) - Ex-voto pré-romano inédito do Museu Regional de Sintra. Revista de Guimarães, 64 (3/4), p. 290-297.

FONTES, J. (1916) - Sur un moule pour faucilles de bronze provenant du Casai de Rocanes. O Arqueólogo Português, 21, p. 337-347.

GAMITO, T. J. (1988) - Social complexity in southern Iberia 800-300 BC. The case of Tartessos. BAR International Series. Oxford.

Gomes, M. V. (1986) - O touro da herdade de Corte Pereiro (Alcácer do Sal). Trabalhos de Arqueologia do Sul, 1, p. 59-73. 
Gomes, M. V. (1992 a) - As comunicações na Proto-história em Portugal. Cuadernos de San Benito, 3, p. 17-30. Fundación San Benito de Alcántara. Madrid.

Gomes, M. V. (1992 b) - A Idade do Bronze Final. In Proto-história de Portugal. Universidade Aberta, 36, p. 103-125.

Gomes, M. V. (1995 a) - A sepultura da Roça do Casal do Meio. In A Idade do Bronze em Portugal, p. 94. Instituto Português de Museus. Lisboa.

Gomes, M. V. (1995 b) - As esteias funerárias da Idade do Bronze Final, no centro e sul de Portugal. In A Idade do Bronze em Portugal, p. 130. Instituto Português de Museus. Lisboa.

González-Prats, A.; Ruiz Segura, E.; Fuensanta, J. G. \& Seva Román, R. (1995)

- Cerámicas anatólicas en el poblado calcolitico de Les Moreres (Crevillente, Alicante, España). Trab. Antropol. Etnol., 35 (1), p. 133-137.

Kalb, P. (1980) - O "Bronze Atlântico" em Portugal. Actas do Seminário de Arqueologia do Noroeste Peninsular, 1, p. 112-138. Sociedade de Martins Sarmento. Guimarães.

Kalb, P. \& Hock, M. (1981/82) - Cabeço da Bruxa, Alpiarça (Distrito de Santarém). Relatório preliminar da escavação de Janeiro e Fevereiro de 1979. Portugalia, N. S.,2/3, p. 61-69.

KALB, P. \& HoCK, M. (1988) - O povoamento pré-histórico de Alpiarça. Arqueologia, 17, p. 193-200.

MAIA, M. (1978) - Ânforas neopúnicas do sul de Portugal. Actas das III Jornadas Arqueológicas da Associação dos Arqueólogos Portugueses (Lisboa, 1977), 1, p. 199-207.

MAIA, M. \& MAIA, M. (1986) - Arqueologia da área mineira de Neves-Corvo. Trabalhos realizados no triénio 1982-84. Somincor. Lisboa.

MARQues, G. (1982/83) - Aspectos da Proto-história do território português. II Povoado de santa Eufémia (Sintra). Sintria, 1/2, p. 59-88.

MARQues, G. \& ANDRADE, G. M. (1974) - Aspectos da Proto-história do território português. I - Definição e distribuição geográfica da Cultura de Alpiarça (Idade do Ferro). Actas do III Congresso Nacional de Arqueologia (Porto, 1973), 1, p. 125-148.

MAtos, J. L. de (1994) - As escavações no interior dos claustros da Sé e o seu contributo para o conhecimento das origens de Lisboa. In O Livro de Lisboa (coord. I. Moita), p. 32-34. Livros Horizonte. Lisboa.

Mayet, F. \& Silva, C. T. da (1993) - Presença fenícia no baixo Sado. Estudos Orientais, 4, p. 127-142.

MAYET, F. \& SILVA, C. T. da (1994) - L'établissement phénicien d'Abul (Alcácer do Sal). Les Dossiers de VArchéologie, 198, p. 22-25. Faton. Quétigny.

Parreira, R. (1995) - Aspectos da Idade do Bronze no Alentejo interior. In A Idade do Bronze em Portugal, p. 131-134. Instituto Português de Museus. Lisboa.

Pautreau, J. P.; Gendron, C. \& Bourhis, J. R. (1983/84) - L'Âge du Bronze en Deux-Sèvres (2500-800 av. J. C.). Musée de Niort.

Pellicer, M. (1978) - Tipología y cronología de las ánforas prerromanas del Guadalquivir, según el Cerro Macareno (Sevilla). Habis, 9, p. 365-400.

Conimbriga, 34 (1995), 33-74 
Pellicer, M. (1979/80) - Ensayo de periodizacion y cronologia tartesia y turdetana. Habis, 10-11, p. 307-333.

PEREIRA, F. A. (1957) - Sintra do pretérito. Câmara Municipal de Sintra.

Pereira, G. (1894) - O collar da Penha Verde. Bol. Real Assoc. Arch. Civis e Archeol. Port., 7 (1), p. 77-78.

PereirA, I. (1993) - Figueira da Foz. Santa Olaia. Estudos Orientais, 4, p. 285-304.

PIMENTA, F. C. (1982/83) - Subsídios para o estudo do material anfórico conservado no Museu Regional de Sintra. Sintria, 1/2, p. 117-150.

PInTO, C. V. \& PARReIRA, R. (1978) - Contribuição para o estudo do Bronze Final e do Ferro inicial a Norte do estuário do Tejo. Actas das III Jornadas Arqueológicas da Associação dos Arqueólogos Portugueses (Lisboa, 1977), 1, p. 147-163.

PONTE, S. da (1982/83 a) - Bronze ibérico votivo de Sintra. Sintria, 1/2, p. 89-94.

PONTE, S. da (1982/83 b) - Algumas fíbulas dos concelhos de Sintra, Cascais, Amadora e Alenquer. Sintra, 1/2, p. 107-116.

RIBEIRO, J. C. (1982/83) - Estudos histórico-epigráficos em torno da figura de L. Ivlivs Maelo Cavdicvs. Sintria, 1/2, p. 151-476.

RIBEIRO, J. C. (1983) - Contributos para o conhecimento de cultos e devoções de cariz aquático relativos ao território do Municipio Olisiponense. Bol. Cultural da Ass. Distr. Lisboa, 89 (1), p. 331-369.

RochA, A. dos S. (1905/08) - Estações pré-históricas da Idade do Ferro nas visinhanças da Figueira. Portugalia, 2, p. 301-359.

Rufete TOMiCO, P. (1988/89) - Las cerámicas con engobe rojo de Huelva. Huelva Arqueológica, 10/11 (3), p. 11-40.

SCHUBART, H. (1965) - Atalaia. Uma necrópole da Idade do Bronze no Baixo Alentejo. Arquivo de Beja, 22, p. 7-136.

SCHUBART, H. (1982) - Asentamientos fenicios en la costa meridional de la Peninsula Iberica. Huelva Arqueológica, 6, p. 71-99.

SCHUBART, H. (1987) - Hallazgos fenicios y del Bronce Final en la desembocadura del rio Guadiaro (Cadiz). Anuario Arqueológico de Andaluzia, 1986, p. 200-227.

SCHUBART, H. (1988 a) - Los primeros asentamientos fenicios en las costas de la Peninsula Iberica. Homenatge a Enrique Pia y Ballester, p. 31-43. Diputació de Valencia.

SCHUBART, H. (1988 b) - Alarcón, Vorbericht über die Grabungs-Kampagne 1984 im Bereich der phönizischen Siedlung und der Befestigungsmaner. Madrider Beiträge, Band 14, p. 172-188.

Schubart, H. \& NiEMEYeR, H. G. (1976) - Trayamar. Los hipogeos fenicios y el asentamiento en la desembocadura del rio Algarrobo. Excavaciones Arqueológicas en España, 90. Madrid.

SchubART, H. \& MAASS-LindemanN, G. (1984) - Toscanos. El asentamiento fenicio occidental en la desembocadura del río de Vélez. Excavaciones de 1971. Noticiario Arqueológico Hispanico, 18. Madrid.

Schubart, H.; Niemeyer, H. G. \& Pellicer Catalán, M. (1969) - Toscanos. La factoría paleopùnica en la desembocadura del río de Vélez. Excavaciones Arqueológicas en España, 66. Madrid.

Conimbriga, 34 (1995), 33-74 
SenNA-MARTINeZ, J. C. de (1989) - Pré-história recente da bacia do médio e alto Mondego: algumas contribuições para um modelo sociocultural. Tese de doutoramento em Pré-história e Arqueologia, 3 voi., ed. policopiada. Faculdade de Letras, Universidade de Lisboa.

SenNA-MartineZ, J. C. de (1994) - Entre Atlântico e Mediterrâneo: algumas reflexões sobre o Grupo Baiões/Santa Luzia e o desenvolvimento do Bronze Final peninsular. Trabalhos de Arqueologia da EAM, 2, p. 215-232. Ed. Colibri. Lisboa.

SERRÃO, E. da C. (1964) - A necrópole proto-histórica do Casalão - Sesimbra. Junta Distrital de Setúbal.

SERrÃO, E. da C. (1966) - Bronzes de Alfarim e de Pedreiras, Sesimbra. Subsídios para o estudo do Bronze Atlântico. In Memoriam do Abade Henri Breuil, 2, p. 303-330. Faculdade de Letras. Lisboa.

SERrÃO, E. da C. (1980) - A sepultura do Rei Mouro (uma estação da Idade do Ferro) - Negrais (Sintra). Arqueologia, 1, p. 28-35.

SERRÃO, E. da C. (1994) - Carta arqueológica do concelho de Sesimbra. Do Vilafranquiano médio até 1200 d. C. Câmara Municipal de Sesimbra.

Silva, A. V. da (1960) - Fantasia sobre a origem do nome de Lisboa. Dispersos, 3, p. 321-331. Câmara Municipal de Lisboa.

Silva, J. da (1879) - Tumulo da Idade de (sic) Pedra. Boi Real Assoe. Arq. Civis e Arqeol. Port., S. II, 2 (10), p. 177.

Silva, C. T. da \& SoAReS, J. (1986) - Arqueologia da Arrabida. Col. Parques Naturais, 15. SNPRCN. Lisboa.

Silva, C. T. da; SoAres, J.; Beirão, C. de M.; DiAS, L. F. \& Coelho-Sohres, A. (1980/81 ) - Escavações arqueológicas no castelo de Alcácer do Sal (campanha de 1979). Setúbal Arqueológica, 6/7, p. 141-218.

SoARes, J. \& Silva, C. T. da (1979) - Cerâmica pré-romana de Miróbriga. Setúbal Arqueológica, 5, p. 159-184.

Spindler, K.; Castello-Branco, A. de; ZByszewski, G. \& Ferreira, O. da V. (1973/74) - Le monument à coupole de Läge du Bronze Final de la Roça de Casal do Meio (Calhariz). Comunic. Ser. Geol. Port., 51, p. 91-153.

TEJERA-GASPAR, A. (1980) - El Bronce Final del bajo Guadalquivir y su problematica. Huelva Arqueológica, 4, p. 181-196.

Theobald, N. (1972) - Fondements géologiques de la Préhistoire. Masson. Paris.

VASCONCELOS, J. L. de (1905) - Religiões da Lusitania, 2. Imprensa Nacional. Lisboa.

VAsConcelos, J. L. de (1920) - Hierologia lusitanica. O Arqueólogo Português, 20, p. 270-286.

VicEnTE, E. P. \& ANDRADE, G. M. (1971) - A estação arqueológica do cabeço de Moinhos. Breve notícia. Actas do II Congresso Nacional de Arqueologia (Coimbra, 1970), 2, p. 223-238.

Trindade, L. \& FerReIRA, O. da V. (1965) - Acerca do vaso "piriforme" tartéssico de bronze do Museu de Torres Vedras. Boi. Cultural da Junta Distrital de Lisboa, 63/64, p. 175-183.

WAGNER, C.G. (1995) - Fenicios y autóctones en Tartessos. Consideraciones sobre las relaciones coloniales y la dinámica de cambio en el suroeste de la Península Ibérica. Trabajos de Prehistoria, 52 (1), 109-126.

Conimbriga, 34 (1995), 33-74 